\title{
Rooftop Solar PV Penetration Impacts on Distribution Network and Further Growth Factors-A Comprehensive Review
}

\author{
Busra Uzum $^{1}$, Ahmet Onen ${ }^{2}$ (D), Hany M. Hasanien ${ }^{3}(\mathbb{D})$ and S. M. Muyeen ${ }^{4, *(D)}$ \\ 1 Electrical-Computer Engineering Department, Abdullah Gül University, 38080 Kayseri, Turkey; \\ busra.uzum@agu.edu.tr \\ 2 Electrical-Electronics Engineering Department, Abdullah Gül University, 38080 Kayseri, Turkey; \\ ahmet.onen@agu.edu.tr \\ 3 Electrical Engineering Department, Faculty of Engineering and Technology, Future University in Egypt, \\ Cairo 11835, Egypt; hanyhasanien@ieee.org \\ 4 School of Electrical Engineering Computing and Mathematical Sciences, Curtin University, \\ Perth, WA 6845, Australia \\ * Correspondence: sm.muyeen@curtin.edu.au
}

Citation: Uzum, B.; Onen, A.; Hasanien, H.M.; Muyeen, S.M. Rooftop Solar PV Penetration Impacts on Distribution Network and Further Growth Factors-A Comprehensive Review. Electronics 2021, 10, 55. https://doi.org/10.3390/electronics 10010055

Received: 23 November 2020 Accepted: 24 December 2020 Published: 31 December 2020

Publisher's Note: MDPI stays neutral with regard to jurisdictional clai$\mathrm{ms}$ in published maps and institutional affiliations.

Copyright: (C) 2020 by the authors. Licensee MDPI, Basel, Switzerland. This article is an open access article distributed under the terms and conditions of the Creative Commons Attribution (CC BY) license (https:// creativecommons.org/licenses/by/ $4.0 /)$.

\begin{abstract}
In order to meet the electricity needs of domestic or commercial buildings, solar energy is more attractive than other renewable energy sources in terms of its simplicity of installation, less dependence on the field and its economy. It is possible to extract solar energy from photovoltaic (PV) including rooftop, ground-mounted, and building integrated PV systems. Interest in rooftop PV system applications has increased in recent years due to simple installation and not occupying an external area. However, the negative effects of increased PV penetration on the distribution system are troublesome. The power loss, reverse power flow (RPF), voltage fluctuations, voltage unbalance, are causing voltage quality problems in the power network. On the other hand, variations in system frequency, power factor, and harmonics are affecting the power quality. The excessive PV penetration also the root cause of voltage stability and has an adverse effect on protection system. The aim of this article is to extensively examines the impacts of rooftop PV on distribution network and evaluate possible solution methods in terms of the voltage quality, power quality, system protection and system stability. Moreover, it is to present a comparison of the advantages/disadvantages of the solution methods discussed, and an examination of the solution methods in which artificial intelligence, deep learning and machine learning based optimization and techniques are discussed with common methods.
\end{abstract}

Keywords: distribution network; mitigation techniques; rooftop PV; PV faults

\section{Introduction}

The increasing effects of global warming, the use of fossil fuels causing environmental pollution as well as increased demand for energy, increase the interest in using renewable energy such as solar energy. According to the Solar Power Europe 2019 report [1] in Figure 1, the roof-mounted photovoltaic (PV) in 2023 is estimated to be $44 \mathrm{GW}$ with a low probability and $76.5 \mathrm{GW}$ with a high probability. Apart from commercial energy investments, residential or factory rooftop PV systems are a more effective solution to respond to energy demand.

Recently, there have been a global trend towards rooftop PV system installations, and connections to the distribution system increases. In addition to being sustainable, cost effective, environmentally friendly, PV systems also have negative effects such as voltage increase, voltage fluctuation, reverse power flow (RPF), harmonics, frequency distortions, system stability, system faults and protection problems (see Figure 2), which influence the voltage and power quality of the electricity system. 
㐫 $60-$

$40-$

$40-7$
$\quad-\quad 29.7$

$20-$

$0-$
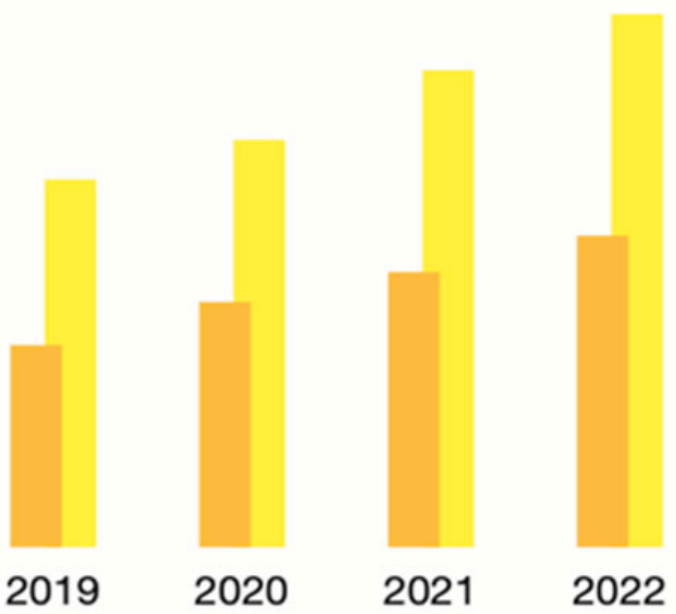

44.0

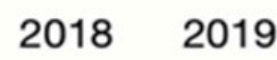

2020

2022

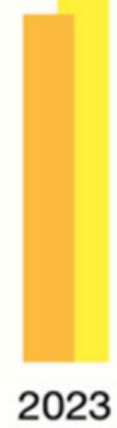

Historical data

Low Scenario

High Scenario

Figure 1. PV installation estimates on the rooftop until 2023 [1].

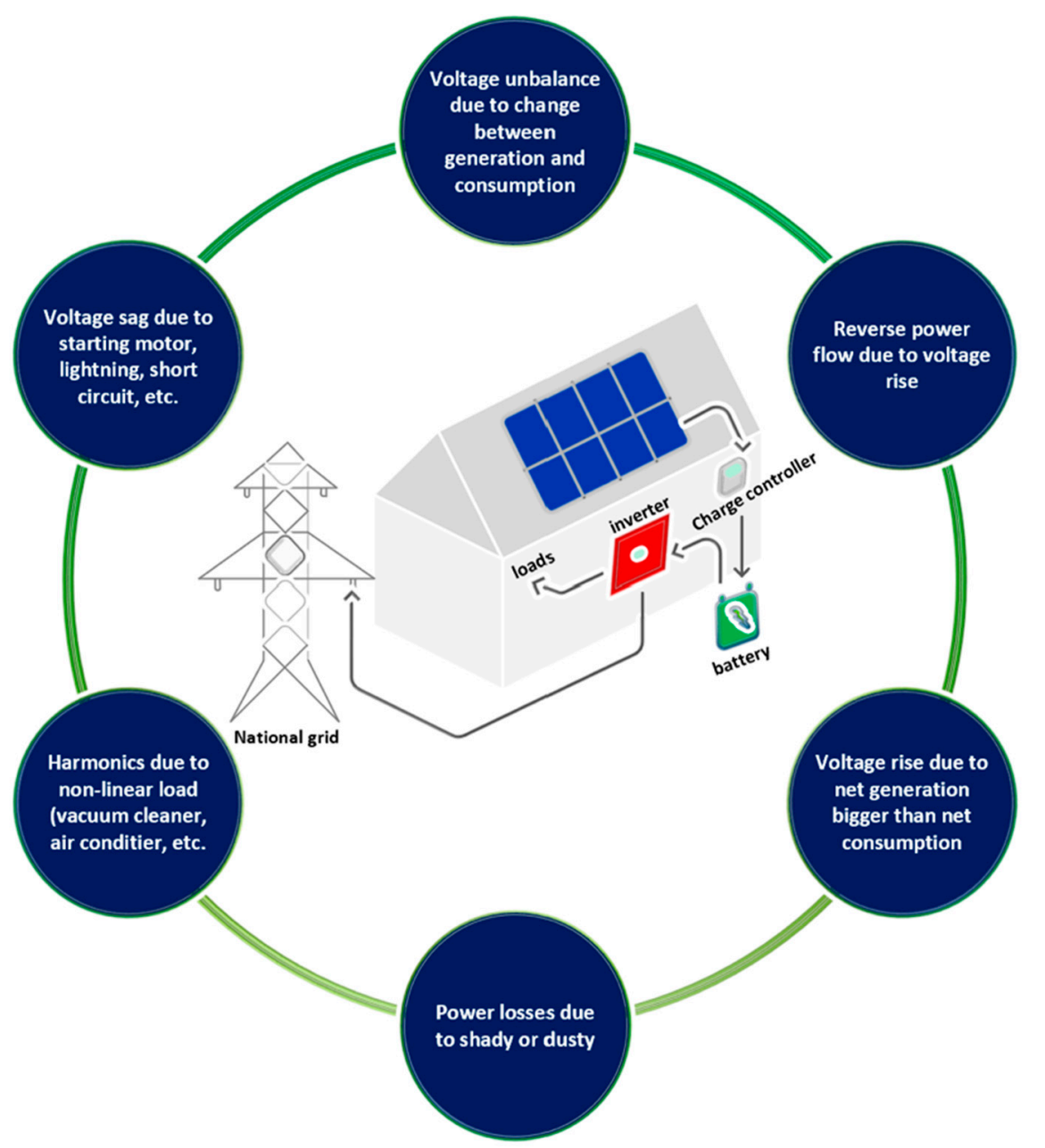

Figure 2. Impacts of rooftop PV. 
In order to take precautions against voltage problems in the PV system, the net energy need of the consumer should be calculated. When the PV output energy is greater than the load, the voltage increases in the system, and consequently, RPF happens. The RPF creates overvoltage in the system, causing the devices in the facility to malfunction. Another important issue to be considered is the shading of the PV panel, its angle due to the sun and its position. To get the best output from PV, it should absorb maximum daylight and it should be ensured that the solar radiation is as perpendicular to the panel surface as possible. Otherwise, problems such as voltage fluctuations and voltage drop will occur. These problems affect power quality, voltage quality, system stability, and cause system protection problems.

In addition to the effects of rooftop PV systems on distribution networks, they also have environmental and economic effects as demonstrated in Figure 3. PV systems have relatively high initial costs and long payback periods. However, with the repurchase guarantee agreements of the governments, investment incentives are paved. Thus, it is predicted that the number of PV systems integrated into the system will increase in the coming years. The problems arising in the power system are increasing due to the increasing applications and traditional methods alone are insufficient to solve the problems. In order for renewable energies to adapt to today's smart grid systems, it is essential to use optimization, artificial intelligence and evolved algorithms that process big data and make accurate predictions for the future with day-ahead or annual data [2-9].

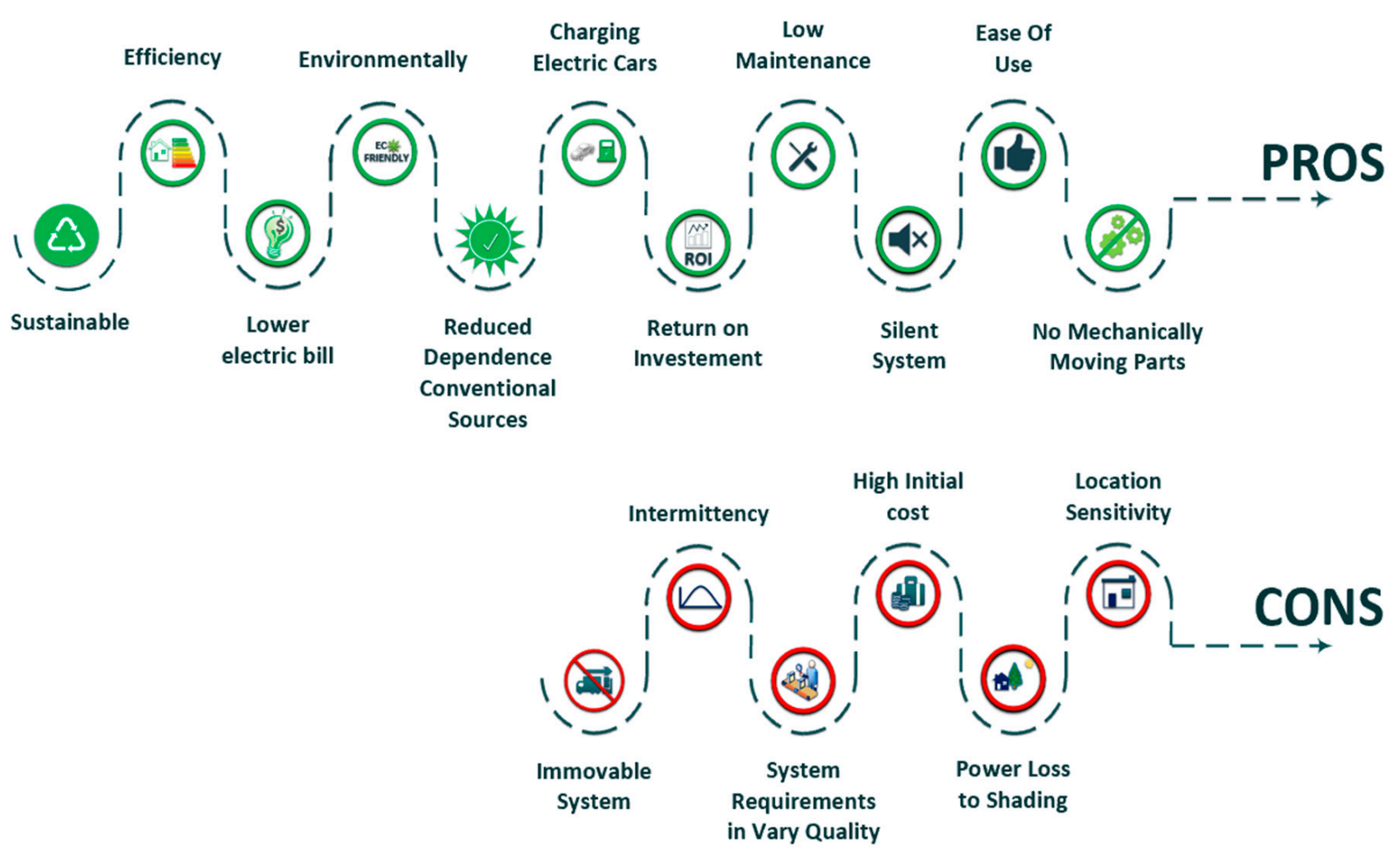

Figure 3. Advantage and problems of residential PV systems.

In this context, this article provides a comprehensive review of the impacts of rooftop PVs on the distribution network and possible solutions to eliminate these effects. In [10], stochastic and deterministic techniques developed to model the uncertainty of rooftop PVs are evaluated. In [11], possible reduction methods are mentioned in order to prevent overvoltage caused by high PV penetration. In [12], it examines the voltage quality of rooftop PV systems, their power losses and how they affect the operation of other voltage regulating devices in the system. Moreover, it is mentioned that most of the problems can be alleviated by using smart inverters. In [13], the effects of high PV penetration 
levels on voltage regulation and voltage unbalance and possible solution methods are discussed. In [14], potential solution methods that smoothing power fluctuations as well as voltage unbalance, power fluctuation, frequency and unintentional islanding problems are mentioned. However, this article comprehensively evaluates the impacts of rooftop $\mathrm{PV}$ on distribution network and present possible solution methods in terms of the voltage quality, power quality, system protection and system stability. In addition, it also provides a comparison of the advantages and disadvantages of the solution methods discussed, and an examination of the solution methods in which artificial intelligence, deep learning and machine learning-based optimization and techniques are discussed with common methods.

The paper is structured as follows. Section 2 examines the effects of rooftop PV on distribution systems on voltage quality, power quality, system stability and protection systems. Section 3 comprehensively discusses possible solution methods. Section 4 evaluates a summary of the discussions and the most recent solutions.

\section{Impact of Rooftop PV Prevalence on Distribution Systems}

\subsection{Impacts on Voltage Quality}

\section{a. Power Losses}

Power losses arise from the components that integrate the PV panel into the system, the use of panels with different I\&V characteristics in the same system, shading and contamination of the panel surfaces, increased PV penetration level $[15,16]$. One of the techniques used to decrease power losses in renewable energy systems is to add Distributed Generation (DG) to the system. When DG is added to the renewable energy system, it must be correctly positioned and dimensioned. Otherwise, it may cause the feeder to overload, which could result in power losses [17]. If the energy generated from PV panels surpasses the net demand of the consumer, it is returned to the network and as a result, the feeder current changes [18]. The change of feeder current in the network can be triggered further with the high-level PV penetration [19] and as a result, power losses increase. In [20], the authors have proposed a voltage and demand management approach, that greatly increased the capacity of distribution networks to absorb and use PV production for distributed battery storages. The simulations have been performed in an imbalanced three-phase distribution network by loads that change every $15 \mathrm{~min}$ in a 24-h time period. They have found that as a result of four different cases, losses decreased significantly, voltage stability increased, and consequently, they could be produced better quality and safer voltages.

Power losses in the presence/absence of a $1 \mathrm{MWp}$ photovoltaic system installed on the rooftop of the Kaohsiung World Games Stadium have examined. Authors have improved to $\mathrm{PV}$ power generation model of recording surface temperature and radiation of the PV panels to more efficiently determine power generation. The data have been obtained from the test feeder showed that the daily power loss decreased by $96.4 \mathrm{kWh}$ [16]. Some authors have proposed strategies such as a multi-objective Optimal Power Flow (OPF) [21] and a decisive technique of an optimal reference schedule [22] to reduce power losses in generation systems under high PV penetration. In [23], a quite unstable test radial Low Voltage (LV) distribution system has been performed for a summer day in a high PV penetration microgeneration. Variation of power losses has been observed in each test method and self-consumption and storage mode have found to be the most appropriate method.

\section{b. Reverse Power Flow}

Normally, the power into the electricity grid flows toward from high voltage to LV. Energy not used by the consumer reverses the direction of the power flow and thus, the direction of power flow changes [24].

Generally, rooftop PV systems are directly connected to distribution networks. However, the storage devices assist to reduce voltage rise and reverse power flow problems. While this reduction is limited by the size of the storage devices, it can be substantially 
reduced with adequate storage size. In [25] where a rooftop PV system with and without storage systems was observed, it has been concluded that the use of the storage system decreased the RPF by $44 \%$.

In [26], the authors have proposed an autonomous energy consumption scheduling algorithm to shave peak load of the rooftop high PV penetration and to decrease RPF. They have formulated stochastic programming due to the PV generating an uncertain amount of power. It has been observed that the proposed algorithm could reduce the voltage increase problem and the peak/average ratio of the total load. In [27], a monitoring technique has been improved to specify the state of the RPF tested with different levels of higher PV penetration. Changes caused by the penetration level as well as the effects of cloud movement on the system have been examined with this development technique. The dynamic ability of the technique has been examined in the IEEE 34-bus three-phase distribution system. Thanks to this development technique, small changes in PV penetration level could be easily detected and the effects of cloud move on the PV system could be observed. Table 1 summarizes the comparison of the different RPF reduction methods in the literature.

Table 1. Comparison analysis between researched techniques.

\begin{tabular}{|c|c|c|c|}
\hline Ref. & System Model & Used Methods & Penetration \\
\hline [28] & 6.6 kV distribution line, $100 / 200 \mathrm{LV}$ lines & SVCs and Battery Energy Storage System (BESS) & $75 \%$ \\
\hline [29] & $11 \mathrm{kV}$ substation and $220 \mathrm{~V}$ feeder network & Smart Loads-plus-Energy Storage System (ESS) & na \\
\hline$[30]$ & 53 residential customers & $\begin{array}{c}\text { Convex optimization based charge/discharge scheduling } \\
\text { algorithm for distributed ESSs }\end{array}$ & na \\
\hline [31] & Two $11 / 0.4 \mathrm{kV}$ radial distribution feeder & Feasible optimization Interval Technique & na \\
\hline$[32]$ & $20 \mathrm{kV} / 0.4 \mathrm{kV}$ & Genetic Algorithm (GA) with linear programming method & 0-93\% \\
\hline [33] & 193 household & Different electric vehicles battery & \\
\hline$[34]$ & na & $\begin{array}{c}\text { Energy management methods by use of the supply and } \\
\text { demand interface }\end{array}$ & $20-100 \%$ \\
\hline [35] & $10 \mathrm{kV}$ (upper grid) $-0.4 \mathrm{kV}$ (LV grid) & $\begin{array}{l}\text { A multi-objective optimization algorithm, a charging } \\
\text { algorithm, GA }\end{array}$ & $40 \%$ \\
\hline
\end{tabular}

\section{c. Voltage Rise}

Voltage increase is the most common challenge caused by RPF. When electricity generated from PV exceeds the consumer load, the voltage at the Point of Common Coupling (PCC) of the inverter and the grid increases [36]. Reducing the increased voltage in the network is the most suitable technique to decrease the negative factors of high PV level [37]. In this regard, lots of control methods have been proposed. Ref. [38] has developed an integrated control method using static synchronous compensators and BESSs to avoid overvoltage in the PV system, [39] has developed a coordinated control of distributed ESS with conventional Voltage Regulators (VRs) involving in the On Load Tap Changer (OLTC) transformers and Step VRs, in [40] an intelligent control method for charging/discharging function has been improved to be efficient use of the existing battery capacity has proposed with the aim of the diminish of voltage increase problem. As a result, it has been observed that the proposed methods were suitable for mitigation the voltage increase problem. In [41], the authors have developed an index-based methodology to examine the effect on the voltage increase caused by the RPF in a high-level PV penetration distribution network. By combining this methodology with the voltage increase mitigation methods, the voltage reasoned by the RPF could be optimized.

\section{d. Voltage Unbalance}

Significant increases in PV systems installed on the rooftop cause problems such as voltage unbalance, disrupting the power quality of the grid [21]. Voltage unbalance occurs due to uncertain current and impedance caused by unbalance between net demand and net generation and also, voltage unbalance gradually increases due to the irregular placement of PV panels [13]. In [42], the authors have proposed an energy storage device to reduce 
the voltage unbalance in the grid under high PV level, and also, have developed a control algorithm by using Lab view ${ }^{\mathrm{TM}}$. The proposed method is effective in balancing the voltage, but the effectiveness of the method varies depending on the location of the storage device in the network.

Another factor causing voltage unbalance is that current imbalances due to the single phase of the consumer side. The system has been installed power must be limited to minimize this negative effect triggering voltage unbalance in the network [43]. In [44] has investigated two diverse strategies such as Dynamic Voltage Regulator (DVR) and Distribution Static Synchronous Balancer (DSTATCOM) special power units to enhance the voltage profile and the voltage unbalance in installed single-phase rooftop PVs. A Monte Carlo based stochastic strategy has been improved to specify the position of PV in the network, the PV rating and uncertain loads. Moreover, a converter topology-control algorithm and a state feedback control based on the pole-shift method have been improved to balance the grid voltage at the PCC of DSTATCOM and DVR. According to the numerical analysis, it has been concluded that DSTATCOM is a more effective method than the DVR in improving the voltage unbalance problem.

Although the voltage is balanced on the generator side, to resolve for voltage unbalance caused by single-phase load and transformer and unbalanced impedance, electricity distribution companies try to spread out the loads evenly between the phases [45]. In [46], Monte-Carlo and Pareto techniques have been improved to balance the voltage in grids with a high level of single-phase generators. The result of optimization has shown that the voltage unbalance could be decreased thanks to the method.

\section{e. Voltage Fluctuations}

Voltage fluctuation is the voltage change between the generation and consumption point along the distribution line [47]. Since voltage fluctuations occur when the voltage at the PCC surpasses a certain limit, the voltage variations must be within certain permissible ranges [48]. These limits are determined by long-period and short-period flicker severity indices. These indices should not be more than 1 in the shortest period and 0.65 in the long period [49]. Voltage fluctuations in renewable DG systems are often caused by bad weather or connection problems [50], which can lead to power quality problems. Ref. [51] has presented a test study involving a cloud shadow technique to solve technical difficulties like power and voltage fluctuations. Results of the simulation showed that fluctuations at $50 \%$ levels of PV penetration could be tolerated.

Voltage fluctuations can lead to interruptions in electricity generation, which can lead to deterioration of devices within the system, leading to economic loss and reduced energy generation for the system owner [52]. LV feeders can cause voltage fluctuations at the output of the photovoltaic panel, as they are usually located at a specific distance from the main substation center and often have low power or failure levels [53]. Ref. [54] has developed a bilevel optimization method based on GA that decreases fluctuations reasoned by high-level of PV by distributing BESSs between allowed nodes of the distribution system. The developed optimization test has been experimented on the IEEE-8500 Node test feeder, and it has been observed that the developed method made coherent decisions which seem optimal.

\section{f. Reactive Power Flow Fluctuations}

Reactive power flow fluctuations in the PV integrated DG system happen due to frequently activating/deactivating the capacitors, OLTCs and line VRs [19]. The high level of PV and the variability of solar radiation further trigger increasing of the reactive power flow fluctuations [55]. Some methods are proposed to inhibit reactive power fluctuations in the literature. In [56], a new multi-objective OPF formulation has been improved to arrange the reactive power fluctuations of PV inverters in a high-level PV integrated system. The developed approach has been observed to crucially increase the damping and stability of the reactive power. A flexible active power control (APC)/reactive power control (RPC) method has been developed based on instantaneous and average APC/RPC 
methods to significantly prevent power fluctuations in [57]. The effectiveness of the method has been tested and validated through PSCAD/EMTDC software. In [58], the authors have developed a calculated strategy of PV inverter current reference to eliminate some degree of active power fluctuations in some degree reactive power under unbalanced voltage drop. The test results of the developed method confirm the validity of the method and indicated that it can be performed in a network-connected inverter to solve power fluctuation problems.

\subsection{Impacts on Power Quality}

a. Frequency

Frequency significantly affects the power quality. A variation of the load leads to frequency deviations in the grid, and the frequency is further impaired, as the active power at the PV output changes due to solar radiation [14]. The actual power may be risen by the fall of the frequency generated by losses in generation and risen load. Moreover, generator emulation controls do this by directing the inverter to decrease actual power generated, as the line frequency increases [59]. In times of high energy consumption, the need for energy increases, and the frequency decreases further. Grid-connected PV systems require a stable frequency for proper operation, and the inverter must have a frequency fault of less than $2 \%$ [60].

In grid-mounted PV systems, BESSs solve many problems as well as frequency problems [61]. The influence of PV on the system frequency in the $20 \mathrm{kV}$ distribution network with PV integration in Indonesia has been examined and a study has been performed to specify the peak level of PV [62]. According to simulation results, the peak level of PV that could be enabled that integrate to the grid is $20 \%$, and so the lowest frequency is $48 \mathrm{~Hz}$. Major data flow over the network brings about cyber-physical difficulties, and the cyber-attack that carried out to smart inverter communication and control signal that taking part in with the PV penetration system may cause the voltage and frequency instability [63]. In [64], a frequency control strategy has been presented to control the variable load frequency in a power system in which the interconnected PV system, and the BESSs have integrated into a sample two-zone thermal power system.

\section{b. Harmonics}

It is expected to alternative current and alternative voltage waveforms are sinusoidal. Sinusoidal waveform distorted and frequency-modified waveforms are called harmonics. Harmonics occur due to non-linear loads such as vacuum cleaners, air conditioners, transformers, etc. Harmonics can further increase because of the integration of high-level PV into the network, and the harmonic resonances, that occur at the PCC. Harmonics have negative effects on the system such as incorrect opening of circuit breakers, deterioration of the isolation of the devices connected to the system. Consequently, these negative effects cause shortening of the life of devices, increasing losses in the network due to heat, and voltage drops [65-67].

In order to produce better quality voltage, harmonics should be reduced, and total harmonic distortion should not surpass 5\% as far as IEEE 1547 and IEC 61727 standards [68]. Inverters are used to eliminate harmonics, but active or passive filters, which are cheaper and simpler, are also preferred [69]. In [70], a two-layer control strategy has been developed for a 37-bus harmonic distribution system by the integration of PV. In the first layer, the most appropriate reactive power and control settings have been specified and these data have been trained in a NN. This NN in the 2nd layer has been utilized in online reactive power adjustment based on actual PV power online. As far as simulation results have been obtained by using a Parallel-Particle Swarm Optimization (P-PSO) algorithm for optimization. According to the results, total harmonic distortion has tended to decrease. In [9], to develop power quality in the network, the use of capacitor-less DSTATCOM has been recommended. The developed method has based on a matrix converter controlled by the control set Model Predictive Controller. As a result of simulation and analysis, the 
developed capacitor-less DSTATCOM could ensure the necessary power factor rectification and harmonic reduction to nonlinear loads connected to the LV side of the grid.

\section{c. Power Factor}

The power factor is a measure of the phase difference between current and voltage in AC systems. Active power is described as utility power in AC systems. Moreover, reactive power is the blind power that does not work, but it required for the excitation of the magnetic circuit. In PV integrated networks, the power factor value of the system changes subjecting to the PV penetration, and so, the significance of power factor correction increases in the networks with high PV penetration level. However, since PV panels cannot generate reactive power, when the PV level increases, the power factor in the system decreases, and consequently system losses increase. The ideal power factor value should be in the range of 0.95 to 1 . According to IEEE 1547 and UL 1741, a PV grid is just allowed to run on one power factor [71]. In this case, additional control methods are necessary to advance the power quality. To rise the power factor and produce higher quality power [72], a control scheme consist in the passivity theory has been proposed to ensure extra functions to the inverter of a PV system. When the grid was under inductive load demand conditions, the power factor has been developed independently of the interruption of the PV panel. Simulation and experimental verification studies have been performed using MATLAB/Simulink, and consequently, the proposed control scheme has been observed to provide the inverter with the ability to improve power quality.

\section{d. Voltage Sag}

An instantaneous decrease where the RMS value is decreased for a period ranging from a half-cycle of the voltage to $500 \mathrm{~ms}$ is described as the voltage sag. In general, voltage sags are caused by starting the motors, lightning, short-circuits between phases or between phases and ground, overloading and network failures, and voltage sags continue until the disturbance is rectified with a fuse or breaker [73]. The voltage sag that occurs in the unbalanced grid affects the output voltage of the PV inverter controlled by a balanced approach and causes a serious fluctuation [74]. Voltage sags in the PV system cause harmonics, therefore power losses occur. In the event when the voltage sag is at a certain level, PV systems may separate off from the power system. However, international standards force PV systems not to leave the network during voltage sags for a specific period of time [75]. The currents generated from the PV panel should be risen in order not to decrease the power quality, and ultimately the power produced by it should be preserved. When the system returns to normal, the load should be increased gradually. Because PV generation is kept at a low level, though the voltage sagging problem is resolved [76]. In [77], voltage sag effect has been examined in the PV system which is a similar capacity in diverse locations and a similar location with different capacity. The PV model and the fault possibility model based on Monte-Carlo approach has been developed. It has been examined the effects of a PV power plant on voltage sag and made a simulation model of PV power plant in PSCAD software. The results have shown that the capacity and grid-connected location affected voltage sag frequency comparing to the system without PV. Series Dynamic Braking Resistor (SDBR) has been proposed to eliminate the impact of faults in the network side and thus avoids the voltage sag [78]. The reason why the proposed of SDBR is that it activates just before the circuit breaker because of is a serial device. In addition to improving the voltage drop with this method, it is indicated that the Low Voltage Ride Through capacity of the PV plant will be increased.

\subsection{Impacts on Stability}

\section{a. Dynamic Voltage Stability}

Dynamic voltage stability is described as the ability to return to steady-state operation during and after instant varies or interruptions such as short circuit, line opening, generator loss, and shutdown of any element of the power system [79]. PV panels placed on the roof negatively affect the dynamic voltage stability. While small level PV panels have 
no effect on system stability, high PV penetration systems integrated into power systems cause system stability disturbances. Besides, in some studies, high PV penetration has been observed to affect the system dynamic stability [80-83].

PV systems must be correctly sized and located to enhance stability and network reliability. Since PV systems can be settled closer to load centers than other power stations, they are more prone to increasing the reliability of the network [84]. Dynamic voltage stability is affected not only by high PV penetration but also by solar radiation, temperature, clouding rate, and dynamic modeling of PV panels [85]. These effects should be considered during the planning and modeling of the rooftop PV system. Another situation that affects dynamic voltage stability is voltage collapse. PV panels supply only active power to the grid that they are integrated. With the increasing load conditions in the system, the need for reactive power increases. When sufficient reactive power is not transmitted to the loads, the dynamic performance of the network is influenced [86]. Dynamic voltage support is recommended as a function of PV inverters to enhance stability in [87]. Unlike traditional dynamic voltage support, this method injects reactive and active power using the PV system while sustaining the nominal current value of the inverter. Consequently, the newly developed method provides better voltage support, while it is more competent in improving voltage stability.

\section{b. Static Voltage Stability}

It is important for a network to maintain its stability to operate safely. Voltage collapse significantly affects static stability, causing losses in an active operating system [88]. To make the operation and planning in the best way, it is required to specify the voltage weak range of the network to find the voltage collapse distance, and the static voltage stability when the voltage drops [89]. Static voltage stability changes with increasing load in the grid, the inability of PVs to produce reactive power, and increasing the amount of PV integrated into the grid [88-90]. Moreover, voltage stability indices are used to location the power system, estimate system uncertainties, and determine system stability. The close of the operating point of the power system to the voltage stability limit is very crucial for operators. So, to define the correct index, it is necessary to classify the voltage stability indices in terms of formulation, evaluation, and application [91]. Generally, the load margin index, voltage margin index, and electrical distance margin index are used to determine static stability, and the load margin index in use is more common than other specified methods [92]. In literature, there are studies researching the effects of high PV level on static voltage stability in the network. It has been determined that the static voltage stability of the system increases under the high PV penetration in studies carried out by using the Active Power-Voltage Curve, the developed voltage stability index in [85], and the Reactive Power-Voltage Curve in [93]. However, studies investigating the penetration level of DG have determined that the PV penetration level, which increases the static voltage stability, is maximum $50 \%$ [94-96]. In [97], the static stability of the DG of the power system has been examined. The continuous power flow method has been used to achieve the voltage stability limit point of the power system with DG. It was concluded that the location of DG helps to develop the static voltage stability. [98] has been proposed a central control scheme that offers an appropriate coordination between the reactive power output of the DGs, the substation capacitors, and the OLTC tap position to control voltage levels and increase static voltage stability in case of increased load at both the transmission and distribution system level. This developed method has been optimized by a GA. At the end of the study, it has been determined that the voltage stability margin has improved.

\section{c. Small Signal Stability}

Small signal stability indicates the constant skill of network systems to sustain a steady voltage of the system after exposure to minor interference caused by minor changes in loads and power [99]. In another definition, it is stated that small disturbances of small signal stability result from low-frequency oscillations in power systems ranging from $0.2 \mathrm{~Hz}$ to $2 \mathrm{~Hz}$ [100]. The ability of PVs to generate power varies depending on 
meteorological conditions such as radiation, temperature, and clouding. The intermittent structure of PVs causes the generated power to change constantly. This condition is considered as small disturbances, and low signal stability is of great importance for PV systems, because of the fact that small disturbances occur continuously [101]. While the Maximum Power Point Tracking (MPPT) changes depending on radiation and temperature on the PV system, the parameters of the PV controls change depending on the fluctuation in the network. Moreover, the signal stability of the PV network should not only depend on probabilistic analysis but also focus on control analysis [102]. In order not to affect the probability of small signal stability further, after the net production balance has been achieved with net demand in the PV power system, the rising level of PV penetration should be prevented [103]. Authors research the impacts of the network on small signal stability with the change of PV level. A study based on two different situations i.e., rooftop PVs and utility-scale PV units added to a large system has been performed in [104]. In this method, eigenvalue sensitivity analysis has been used to specify the critical modes of the network. Modal analysis and time domain simulation of the PV system have been used in [105]. In general, research results show that by increasing PV level and incorrect positioning of PV, small signal stability is negatively affected. In [100], small signal stability of the grid has been tested at different PV penetration levels. Three different situations in which Flexible AC Transmission System (FACTS), Static Var Compensator (SVC), and Thyristor Controlled Series Capacitor (TCSC) have been included, and the system has been analyzed according to these situations. The first case was without FACTS, the second case was with SVC, and the third case was with TCSC. Simulation results showed that the situation that TCSC is the most suitable solution for small signal stability in high PV integration systems.

\subsection{Impacts on Protection System}

\section{a. Fault Current}

Fault analysis is required in PV integrated systems to provide the safety of the network and personnel, to sustain the energy, to decrease maintenance-repair costs, and to raise efficiency. The level of the fault current increases because of the risen PV penetration (see Table 2), improper placement of PVs, and additional fault current from the inverter [106].

It is important to identify the faulty area precisely and quickly. Otherwise, the fault current leads to significant security problems and fire hazards in PV arrays. If the PV fault current at the interconnection point is less than $10 \%$ of the total fault current in the $\mathrm{PV}$ network, no problem arises in system protection. Although the contribution of the fault current from small-scale rooftop PV systems is not high on the protection system, it has been observed that the collective contribution causes significant increases with the increasing PV penetration level [107]. For this reason, a protection scheme based on overcurrent coordination is recommended for high penetration rooftop PV systems, considering fault clearance speeds and the requirement of directional element [108]. Moreover, the fault current contribution that occurs in one circuit affects the fault currents in other circuits following the bus. In addition, when the fault current arising from PV is coupled with the transformer fault current in a line, reduced by the transformer center breaker, and this decrease reduces the sensitivity of the relay in the system. This may cause concern in high PV integration systems [109]. All faults that occur in PV systems are shown in Figure 4 [110-114].

In [113], has been examined the line-line faults occurring reasoned by short circuit faults and double earth faults in PV network. Moreover, the behavior of the Overcurrent Protection Device (OCPD) added to protect the elements in PV systems from faults. The authors concluded that OCPDs could detect and clear large fault currents and isolate faulty circuits, but small fault currents were more difficult to detect. In [115], the authors have examined the effects on the central and distributed network at different penetration levels, such as $20 \%, 40 \%$ and $60 \%$ and test studies have been performed using PSCAD/EMDTC software. In addition, the impacts of the various PV levels specified on the overcurrent pro- 
tection system have been examined. It has been stated in the simulation results that the high level of malfunction affects the opening of the protective device faster and this situation has concerned at high penetration levels. Moreover, it has been concluded that the significant increase in short circuit current due to the distance of PVs affect neighboring OCPD.

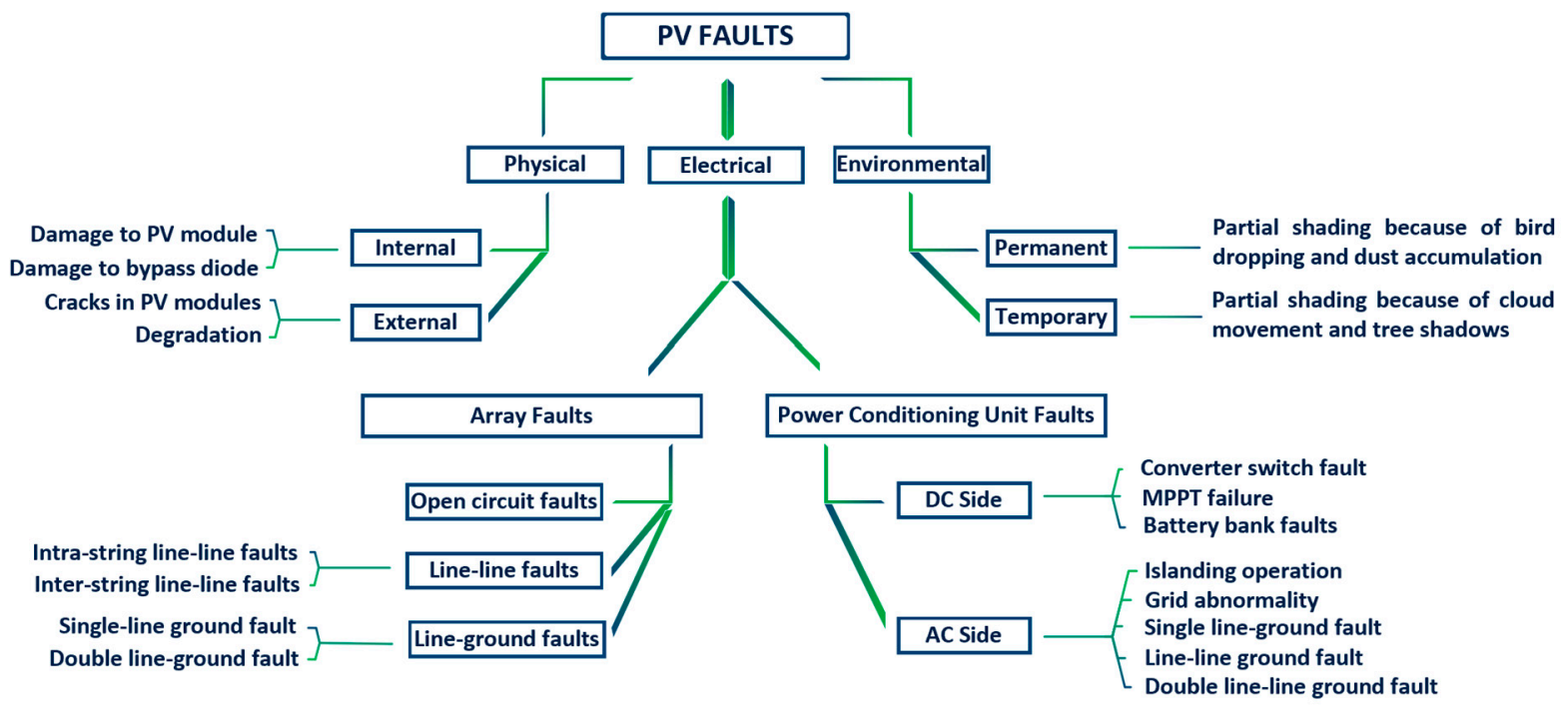

(a)

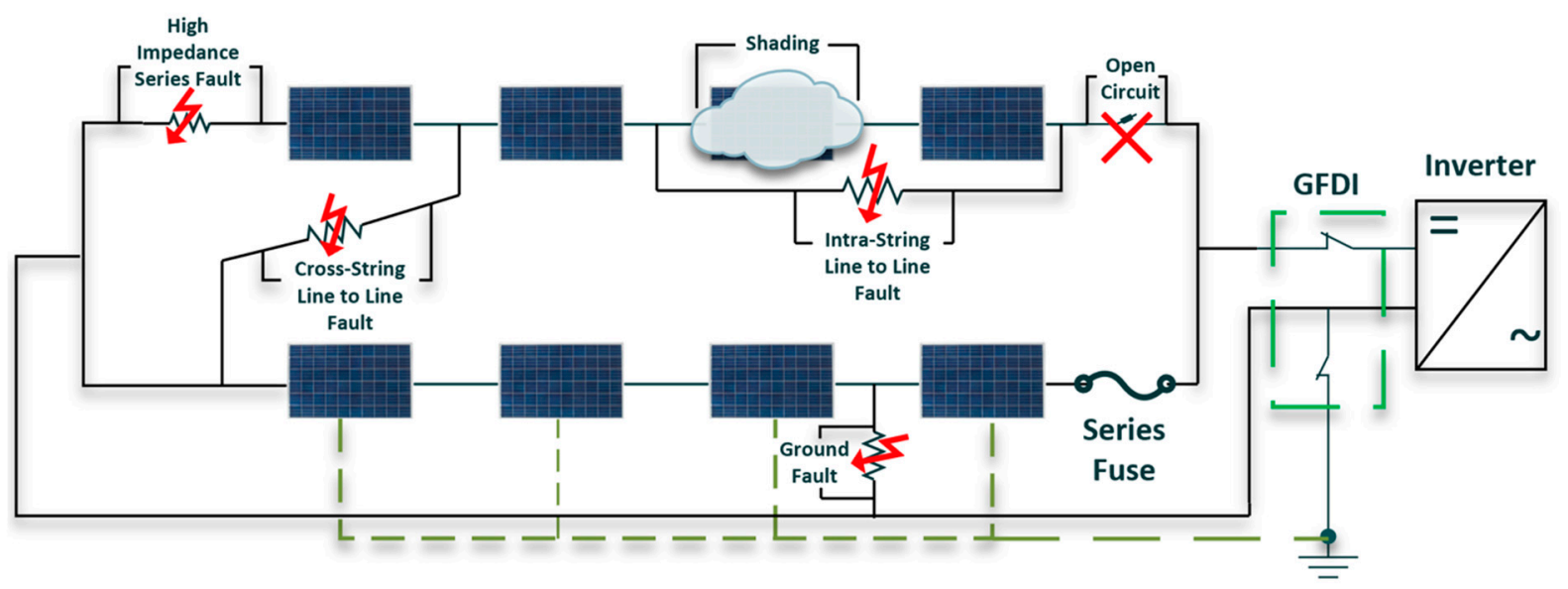

(b)

Figure 4. (a) Various faults on PV system; (b) Types of faults that can occur in PV system and the use of GFDI device.

Table 2. Variation of short circuit currents according to different PV penetration levels.

\begin{tabular}{ccc}
\hline Reference & PV Level & Short Circuit Current (kA) \\
\hline & 0 & 6.06 \\
{$[116]$} & $1996.56 \mathrm{~kW}$ & 6.42 \\
& $3993.12 \mathrm{~kW}$ & 6.77 \\
& $5989.68 \mathrm{~kW}$ & 7.09 \\
\multirow{2}{*}[117]{} & $7986.24 \mathrm{~kW}$ & 7.39 \\
& 0 & 7.73 \\
& $60 \%$ & 7.79 \\
\hline
\end{tabular}




\section{b. Fault Detection}

Increased integration of PV significantly affects protection problems. The fault current (n-1) of $\mathrm{n}$ series connected in parallel can be calculated as $\mathrm{x}$ (short circuit current of each string) [111]. The system control can be more complicated with increased PV penetration. Detection and quick elimination of the fault increases the reliability of the PV system. Monitoring of PV systems is a method used to check in real time, whether PV arrays run smoothly or not. Since the operation of PV arrays is influenced by factors such as solar radiation and temperature, these effects must be taken into account when developing fault detection algorithms so that faster detection method can be developed. Ground Fault Detector Interrupter (GFDI) is generally used in a grounded system with PV. The maximum earth fault current value of the GFDI device is 5A. However, if the fault happening in the PV system is below 5A, the GFDI cannot blow since the error could not be detected. This gap in conventional fault sensing and detection fuses is referred to as the "blind spot" [110]. The blind spot fault is hazardous as it creates a bypass current path for the GFDI interrupt elements [118].

The fault current amplitude of GFDI varies depending on where the earth fault happens in the network, and the ground fault current increases at the same rate, as the value of the voltage at the position of the fault increases. In such a case, potential research studies should be carried out before selecting the insurance to be used in the system to make the fault determination correctly. As a result of the line-to-line fault experiments in the PV arrays [119], it has been determined that the fault location and MPPT are effective in reducing the fault current size, and OCPD fuses could not detect the fault. To remove the "blind spot", statistical contradiction rules have been performed on the PV-string monitoring system. However, it has been observed that some faults have been detected incorrectly. To deal with this situation, the Local Outlier Factor has been developed, showing improved fault detection. The advantages of using Local Outlier Factor are that it is easy to apply, and is suitable for real-time operation, but does not require weather information. As a result of the application, it has been observed that the problem of detecting the fault has been improved. A fault detection scheme based on multi-resolution signal decomposition and fuzzy inference systems has been improved to determine DC side short circuit faults in a PV system with serial/parallel connection in [120]. The use of MPPT in PV systems makes it hard to detect faults under low radiation conditions. As a result, the fault detection technique was efficient and reliable in determining the faults that were difficult to detect due to the use of MPPT.

\section{Solutions to Increase PV Integration}

\section{a. Demand Side Management}

The unbalanced electricity unit price and the unbalance between production and consumption are the major difficulties in PV system-battery applications on the rooftop. Demand Side Management (DSM) applications are developed to manage these challenges. DSM mechanisms are a solution method that encourages them to change loads during periods of peak use, to manage load profiles, for consumers to save on energy use. Moreover, it is a solution method used to optimize existing and planned energy production resources, increase energy efficiency, and balance production and consumption [121-123]. Increasing PV penetration, reducing greenhouse gas emissions, and optimizing energy costs are among the advantages of using the demand-side method. In addition to these advantages, DSM contributes to the regulation of problems like peak shaving, direct load control, capacity market programs, and time of use in PV-battery systems [124]. From the DSM approach, energy may be stored when the cost of energy on the network side is low or if surpass energy generated by the PV is not used. When the grid electricity price is high or the energy generated from PV is insufficient, the stored energy can be used to provide the grid system [125]. As DSM components, it can be expressed as local power plants, smart devices, sensors, ESSs, energy management unit, smart grid areas [126]. 
In [127] provides a Home Energy Management System (HEMS) model that controls the batteries connected to the roof PV system to schedule $24 \mathrm{~h}$ in advance and perform the scheduled battery operation for the target day, considering the electrical load and PV production estimation faults. As a result of estimation accuracies performed on 160 households, it has been observed that it provides certain benefits for one house and the total power system, however, can cause an additional peak load when battery control was used as the number of HEMSs increases. In [26], an autonomous energy consumption timing strategy has been improved to decrease the impact of voltage increase reasoned by RPF under higher PV penetration. Considering the intermittent structure of PV, stochastic programming has been used to formulate the energy consumption timing problem. It has indicated that the improved method as a result of the simulation study can reduce the voltage increase problem under high PV level and decrease the peak/average ratio of the total load.

Different DSM techniques in the literature are summarized in Table 3 [122,123,128-134].

\section{b. On Load Tap Changer}

The PV penetration level is increasing gradually. Problems such as irregular increases, overvoltages, and fluctuations occur in the voltage of the system due to the intermittent nature of PVs. Generally, OLTC is used in PV systems to overcome these problems. The main reason for the use of OLTC is that it allows the voltage regulation in the transformer loaded by changing the tap without interrupting the voltage stability without interruption and safely. Depending on the increased PV penetration level, OLTCs may experience excessive tap changes, which causes OLTCs to wear out and shorten their lifespan. By avoiding unnecessary tap changes and limiting the number of tap operations, the durability and lifetime of OLTC can be increased. In order to have the most efficient OLTC control in a PV system, hourly net PV production and net consumption values should be taken into consideration. OLTCs, which are used to reduce voltage problems in distribution systems, may not be able to cope with this task alone. Innovative methods should be developed to control OLTCs to plan active power management, reduce energy consumption, or keep the voltage within certain limits. In [135], a coordinating control approach has been developed for an OLTC of a distribution substation and PV smart inverters to increase the outage quality under the high PV penetration. The OLTC tap position of the main substation has been specified from the voltage change of the distribution feeders, taking into account hourly generation and consumption values for a day. It has been analyzed in a feeder system affiliated with the Taiwan Power Company and consequently, it has been detected that the distribution feeder's voltage quality has increased significantly and the effect of large PV integration has been effectively reduced.

In [136], rule-based and optimization-based control methods are developed to control transformers installed on on-load tap changers. The first method can be applied in the short term as it uses rules and requires limited observability, while the second method takes into account optimization and full observability. The second method could be an option for the future. The daily average number of step changes is reduced by $95 \%$ with optimizationbased control. In [137], a mixed integer linear programming-based optimization algorithm is proposed that improves voltage quality, reduces consumer electricity cost, and saves energy. In the proposed method, control of OLTC and distributed energy sources are considered. However, since the penetration levels are not taken into account in the studies, the transformer may be overloaded. 
Table 3. Summary of different DSM applications.

\begin{tabular}{|c|c|c|c|c|c|}
\hline Project Implementation Area & Aim & Energy Saving/Contribution & Cost Saving & $\begin{array}{l}\text { Payback } \\
\text { Period }\end{array}$ & Emissions $\mathrm{CO}_{2}$ \\
\hline $\begin{array}{l}\text { Technical University of Ostrava campus, } \\
\text { Czech Republic }\end{array}$ & To reduce the power outage & $\begin{array}{l}\text { With ADSM 45\%-for mayWith } \\
\text { ADSM 48\%- for December }\end{array}$ & na & na & $1590.0 \mathrm{~kg} \cdot \mathrm{yr}^{-1}$ \\
\hline Five households in South Africa & $\begin{array}{l}\text { To decrease the cost of the consumer and } \\
\text { the power consumption from the } \\
\text { network }\end{array}$ & $14 \%$ & $15.21 \%$ & 4.09 years & $\begin{array}{l}\text { Before } 203.44 \mathrm{~kg} \text { After } \\
174.67 \mathrm{~kg}\end{array}$ \\
\hline House in remote area & $\begin{array}{l}\text { To analyze the effect of the load profile } \\
\text { on the hybrid system performances }\end{array}$ & $\begin{array}{c}\text { Energy contribution part increases, } \\
\text { from } 38.41 \% \text { to } 89.5 \% \text { in the summer } \\
\text { season, and from } 33.61 \% \text { to } 47.03 \% \text { in } \\
\text { the winter }\end{array}$ & na & na & $\begin{array}{l}6.52 \% \text {-with DSM in } \\
\text { summer } 4.65 \% \text {-with } \\
\text { DSM in winter }\end{array}$ \\
\hline $\begin{array}{c}\text { A rural health clinic in Karu Local } \\
\text { Government Area of Nasarawa State in } \\
\text { Nigeria }\end{array}$ & $\begin{array}{c}\text { To increase renewable energy penetration, } \\
\text { optimize energy costs and decreases } \\
\text { carbon emissions }\end{array}$ & $25.8 \%$ & $70 \%$ & na & $\begin{array}{c}\text { Before DSM } \\
2579 \mathrm{~kg} / \text { yearAfter DSM } \\
88.22 \mathrm{~kg} / \text { year }(96 \% \\
\text { in total })\end{array}$ \\
\hline Palestinian distribution network & To supply shortages in electrical network & na & 37,470 \$/years & 6.9 years & About 180 ton per annum \\
\hline $\begin{array}{l}\text { PV system with a nominal capacity of } \\
13.2 \mathrm{~kW} \text { and a battery bank system with } \\
\text { an nominal capacity of } 45.6 \mathrm{kWh}\end{array}$ & $\begin{array}{c}\text { To analyze and optimize PV-BESS } \\
\text { system with single-criterion and } \\
\text { multi-criterion optimizations }\end{array}$ & $\begin{array}{l}\text { PV self-consumption by } 15.0 \% \text {, PV } \\
\text { efficiency by } 48.6 \%\end{array}$ & $\$ 16,780$ & na & Reduced $34.7 \%$ \\
\hline $\begin{array}{l}\text { Numerical examples tested in IEEE } \\
\text { 13-node Medium Voltage and CIGRE } \\
\text { 18-node LV distribution systems }\end{array}$ & $\begin{array}{l}\text { To reduce the cost of electricity and } \\
\text { network losses by ensuring the } \\
\text { coordinated operation of HEMS and } \\
\text { Volt/Var Optimization }\end{array}$ & $\begin{array}{c}21.3 \% \text { in LV } 2.34 \% \text { in Medium } \\
\text { Voltage }\end{array}$ & $6.71 \%$ & na & na \\
\hline $\begin{array}{l}\text { UK based house includes rooftop PV } \\
\text { and BESS }\end{array}$ & $\begin{array}{l}\text { Hierarchical two-layer HEMS to reduce } \\
\text { daily household energy costs and } \\
\text { maximize PV self-consumption }\end{array}$ & $21.2 \%$ & $27.8 \%$ & na & na \\
\hline 247 residential prosumers in Austin, TX & $\begin{array}{l}\text { Smart HEMS to optimize appliance } \\
\text { scheduling }\end{array}$ & $21.476 \mathrm{kWh}$ at the end of the day & $32.93 \%$ & na & na \\
\hline
\end{tabular}




\section{c. Reactive Power Control}

PV panels are known to produce only active power. With the increasing rooftop PV applications, the transmission of high active power to the grid creates additional problems such as RPF, voltage fluctuation and voltage unbalance in the network. Generally, only active power is limited to control the voltage in PV systems. However, the reactive power should also be controlled to support the grid voltage statically.

In high voltage PV power systems, RPC is more effective in high voltage systems since the $R / X$ ratio is lower than LV systems. Moreover, the $R / X$ ratio determines the degree of this activity. In addition to considering RPC to increase penetration in high voltage rooftop PV applications, voltage regulation in LV PV systems should be coordinated with RPC and active power control [138]. Recently, inverters have been used to achieve this coordination. Inverters regulate voltage by limiting active power and consuming reactive power. Moreover, the voltage is better regulated when the inverters are integrated into the system with ESSs [139]. To control reactive power, different methods are used such as voltage dependent RPC, constant power factor type control, constant RPC [71]. In addition to these controls, a study has been conducted in [140] investigating single-phase RPC strategies. In the study, constant average active power control, constant active current control, constant peak current control, and thermally optimized RPC methods have been investigated. However, in real PV systems, it is stated that these methods are applied according to the targets to be achieved at the network.

In [141], a study has been performed on the PV penetration rate that can be integrated into the Thailand AG network. To verify the voltage in the LV network, OLTC, RPC and hybrid OLTC-RPC control methods have been tested. It has been determined that the OLTC method is more effective than RPC in terms of controlling reactive power and the hybrid OLTC-RPC method is the most suitable method for high PV penetration systems. As a result of five different configuration studies have been developed using these methods, it has been concluded that high PV penetration could be successfully applied to the system. It has been stated that when higher capacity conductors were integrated into a higher dimensional transformer system with OLTC, the PV ratio could be increased by $50 \%$ to 90\%. However, OLTC tap positions cannot be changed frequently and OLTC can be costly to use in high PV penetration systems. RPC to improve voltage quality in high PV level power systems is combined with optimization methods in future solutions [132,142-144].

\section{d. Energy Storage Systems}

It is recommended to use PV rooftop applications with ESSs to efficiently manage energy, improve grid stability, mitigate the effects of voltage fluctuations, regulate frequency, and solve power quality problems led by high PV penetration. Because of the intermittent and unpredictable nature of the PV panels due to changing meteorological conditions and the variable supply/demand balance, rooftop PVs cause voltage and frequency changes in the network when they are integrated into the power system, especially when the penetration rate is high. The time interval of voltage fluctuations in the power output is less than one minute. Therefore, short-term storage systems such as lead-acid batteries, supercapacitors and li-on batteries help to improve system stability [145]. The integration of solar PV and storage systems into the grid together will increase the stability, reliability, and security of the grid, and furthermore enable grid management [146]. Storage systems must be positioned correctly so that voltage instability can be effectively improved with ESSs. As a matter of fact, as a result of the study in [147], they found that the voltage instability problem could occur again, although the equivalent PV penetration was reduced to a seemingly safe level by $-20 \%$ by the storage units. However, the problem is solved when the storage systems are located on the downstream bus along the distribution line. It is possible to the use energy produced from daytime panels instead of using high-cost mains electricity in evening peak use, thanks to the storage systems.

ESSs are an economical solution that transfers unused energy to the network and eliminates the use of high-cost energy drawn from the network when energy is needed. 
Moreover, problems such as voltage increase due to unused energy, RPF, and energy losses can be reduced by the optimal size of ESSs. In [148], a heuristic control method has been developed using hybrid ESSs to reduce the voltage fluctuations in the PV integrated LV distribution feeder. In this method, a super capacitor has been used to check the rapid fluctuations in the battery storage and PV inverter to a certain size to decrease the voltage increase in the middle of the day. For these purposes, both have been dynamically charged in the middle of the day at the same time and discharged in the evening peak hours. An energy sharing method between the battery storage and the supercapacitor storage has been recommended to ensure uninterrupted control when rapid fluctuations occur during the cloud transition. It showed that the proposed method in the test results could reduce slow and rapid fluctuations in the PV output. In [149], a flywheel-based energy storage solution has been proposed to be an alternative to batteries commonly used in rooftop PV systems. The effectiveness of the method has been tested using real data for a building in Austria. The results have been revealed that a storage size of $5 \mathrm{kWh}$ per household was reasonable, but currently available storage technology prices were still too high to reach an important point in their lifetime. Different ESS applications in the literature are summarized in Table 4 [32,39,131,150-153].

\section{e. Static Synchronous Compensator}

With the increase of PV applications on the rooftop in recent years, challenges such as voltage increase, voltage fluctuations, voltage unbalance and voltage instability occur in distribution networks. These problems affecting the mains power quality and voltage are alleviated by controlling the reactive power in the mains through one of the FACTS types in Figure 5, the Static Synchronous Stabilizer (STATCOM). To regulate the voltage, STATCOM draws reactive power by acting as an inductor at the PCC point when the mains voltage is higher than the nominal voltage, feeding the reactive power by dealing as a capacitor when the main voltage is smaller than the nominal voltage, thus ensuring that the bus voltage is below its limits $[154,155]$. The main purpose of STATCOM is to supply balancing current to the system to correct the power quality caused by voltage imbalance that affects sensitive loads. What makes STATCOM advantageous is its rapid response to the system and its ability to handle system imbalance, minimize harmonics and control the DC voltage on the DC link capacitor compared to the other AC transmission system (FACTS) devices [155]. A STATCOM using a hysteresis current controller is proposed in [156] to decrease the voltage drop due to the sudden load increase. In the study, a current is injected into the system by STATCOM to eliminate the impact of the nonlinear current waveform generated by the load. As a result of the simulation studies, it has been concluded that the developed method entirely compensates for the voltage drop and provides power quality to the enduser. Ref. [157] recommends STATCOM based on hysteresis current control for the voltage imbalance problem of the rooftop PV system. In the proposed study, three case studies have been conducted and the method has been confirmed to be an efficient way to alleviate the voltage imbalance problem. Ref. [158] suggests a method that allows a D-STATCOM to best allocate the capacity of a finite-grade compensator to negative sequence, zero sequence, and reactive power compensation in order to partly compensate for a PV load. 
Table 4. Summary of different ESS applications.

\begin{tabular}{|c|c|c|c|c|c|c|}
\hline Project Implementation Area & Aim & Penetration & Reduced Impact & Cycle & Depth of Discharge & State of Charge \\
\hline 406 domestic loads in the UK & Voltage rise and unbalance & na & Voltage standard deviation $84 \%$ & na & na & $39 \%$ to $47 \%$ \\
\hline $\begin{array}{l}\text { Australian LV distribution } \\
\text { system }\end{array}$ & $\begin{array}{c}\text { Decrease impacts of load and PV } \\
\text { unbalance }\end{array}$ & na & $\begin{array}{c}\text { Current unbalance- midday } 3.6 \% \text { \& } \\
\text { evening } 2.8 \% \text { Neutral current- } \\
\text { midday } 80 \% \text { \& evening } 71 \%\end{array}$ & na & $35 \%$ & $100 \%$ \\
\hline A Belgian residential LV feeder & Quantify the ESS size for voltage support & $23 \%$ & Energy losses about $7.3 \%$ & 1500 & $80 \%$ & $20-90 \%$ \\
\hline LV distribution system & To reduce voltage rise & $\operatorname{Max} 50 \%$ & Reduced energy losses $20 \%$ & 3300 & $20 \%$ & $60 \%$ \\
\hline $\begin{array}{l}\text { LV distribution system located } \\
\text { in Yazd province, Iran }\end{array}$ & $\begin{array}{l}\text { Increasing energy price arbitrage, } \\
\text { decreasing transmission access fee, } \\
\text { environmental emission, and undesired } \\
\text { effects of high PV penetration }\end{array}$ & $93 \%$ & Daily reductions of losses $3.3 \mathrm{~kW}$ & 12,000 & $100 \%$ & na \\
\hline $\begin{array}{c}20 \mathrm{kV} \text { distribution system in } \\
\text { Kabul, Afghanistan }\end{array}$ & Peak load shaving & na & Power losses $20.62 \%$ & na & $75 \%$ & $90 \%$ \\
\hline Low-energy building in China & To analyze and optimize PV-BES system & na & $\begin{array}{c}\text { Standard deviation of net grid } \\
\text { power } 3.4 \% \text { battery cycling aging } \\
78.5 \% \mathrm{CO}_{2} \text { emission } 34.7 \%\end{array}$ & 1000 & na & $25-90 \%$ \\
\hline
\end{tabular}




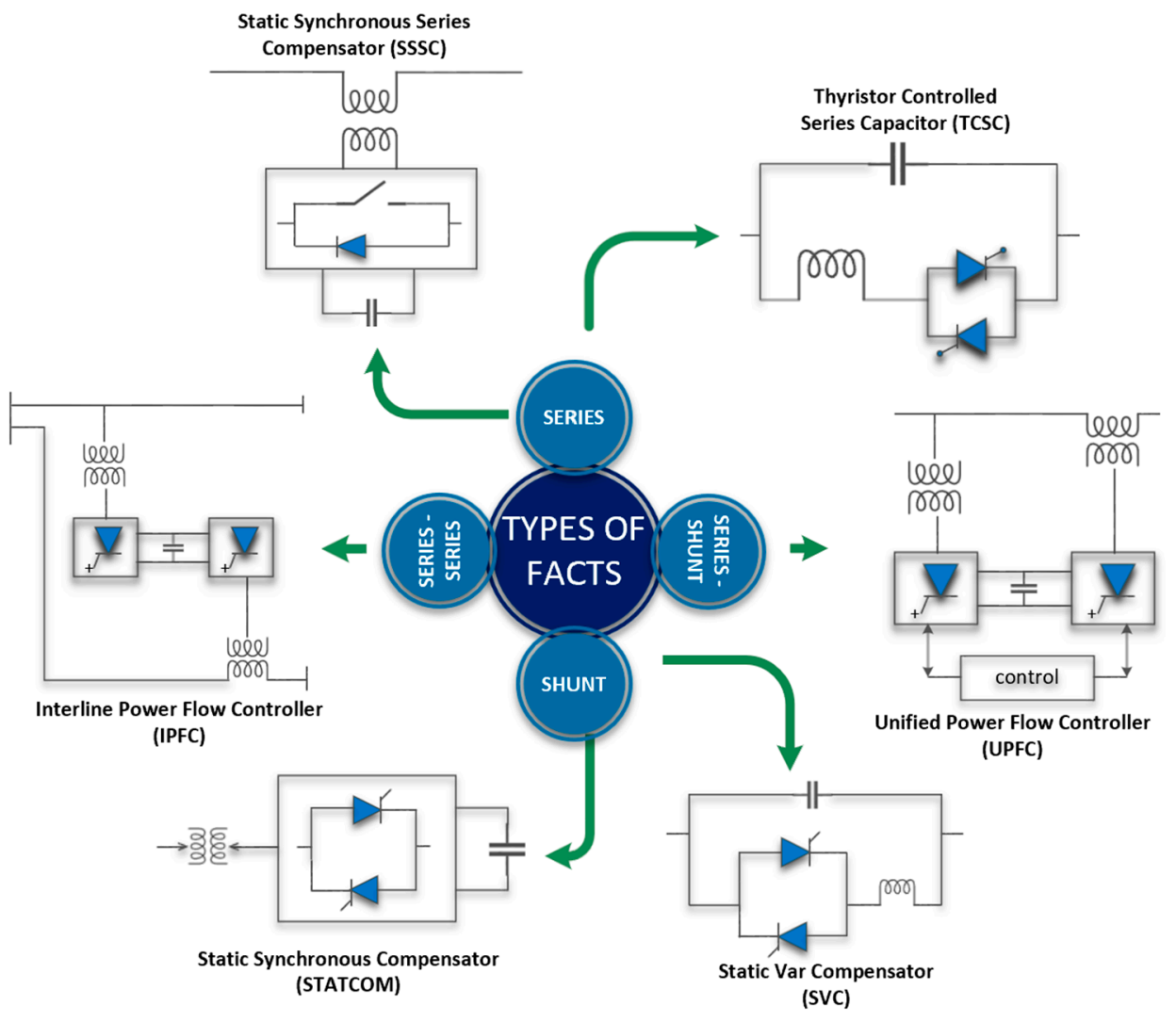

Figure 5. Different types of FACTS devices.

f. PV Generation Curtailment (PVGC)

High-penetration rooftop PV systems that do not use an ESS or whose capacity is insufficient to store the generated energy can create overvoltage in the network to which it is connected. To reduce and coordinate the voltage profile, PVGC or APC techniques can be applied through PV inverters. This method is the generation reduction, in which the active power output is reduced until the system voltage reaches the specified legal limits when an overvoltage occurs [159]. Although the active power shortening strategy requires small changes in the inverter, it is one of the most cost-effective methods, but it is not a preferred method for investors as it causes loss of income. This strategy is recommended only when known voltage control methods are exhausted. Different PVGC methods in the literature are summarized in Table 5 [160,161].

Table 5. Summary of different PVGC methods.

\begin{tabular}{cccc}
\hline Aim & $\begin{array}{c}\text { Project Implementation } \\
\text { Area }\end{array}$ & Loss & $\begin{array}{c}\text { Total } \\
\text { Curtailed } \\
\text { Power }\end{array}$ \\
\hline $\begin{array}{c}\text { To optimize the inverter power to } \\
\text { determine the curtail power required } \\
\text { to prevent overvoltage conditions }\end{array}$ & $\begin{array}{c}\text { A residential in Alice } \\
\text { Springs street in } \\
\text { Australia }\end{array}$ & $35.7 \mathrm{~kW}$ & $55 \%$ \\
\hline $\begin{array}{c}\text { Techno-economic evaluation of } \\
\text { battery storage and PV reduction }\end{array}$ & Residential area in Zurich & $3.2 \%$ & $61.95 \%$ \\
\hline
\end{tabular}




\section{g. Smart Inverter}

Increasing rooftop PV applications cause some operational and safety challenges such as voltage fluctuations, voltage increase, voltage imbalance, and RPFs flows in the network in which they are integrated. Intelligent inverters that can supply/absorb reactive power to the grid are used to overcome these difficulties. Moreover, it receives great attention compared to other control devices as it responds almost instantly to a control signal. Smart inverters can maintain distribution system integrity if the existing distribution system is optimally configured with controllers. Since the reactive power capacity of the PV inverter is restricted by the degree of the inverter and the total level of harmonic distortion measured, the inverter is compelled to generate/absorb reactive power up to a limit set by a certain power factor, thereby eliminating operational disturbances [162]. The benefits of using PV smart inverter are shown in Figure 6.

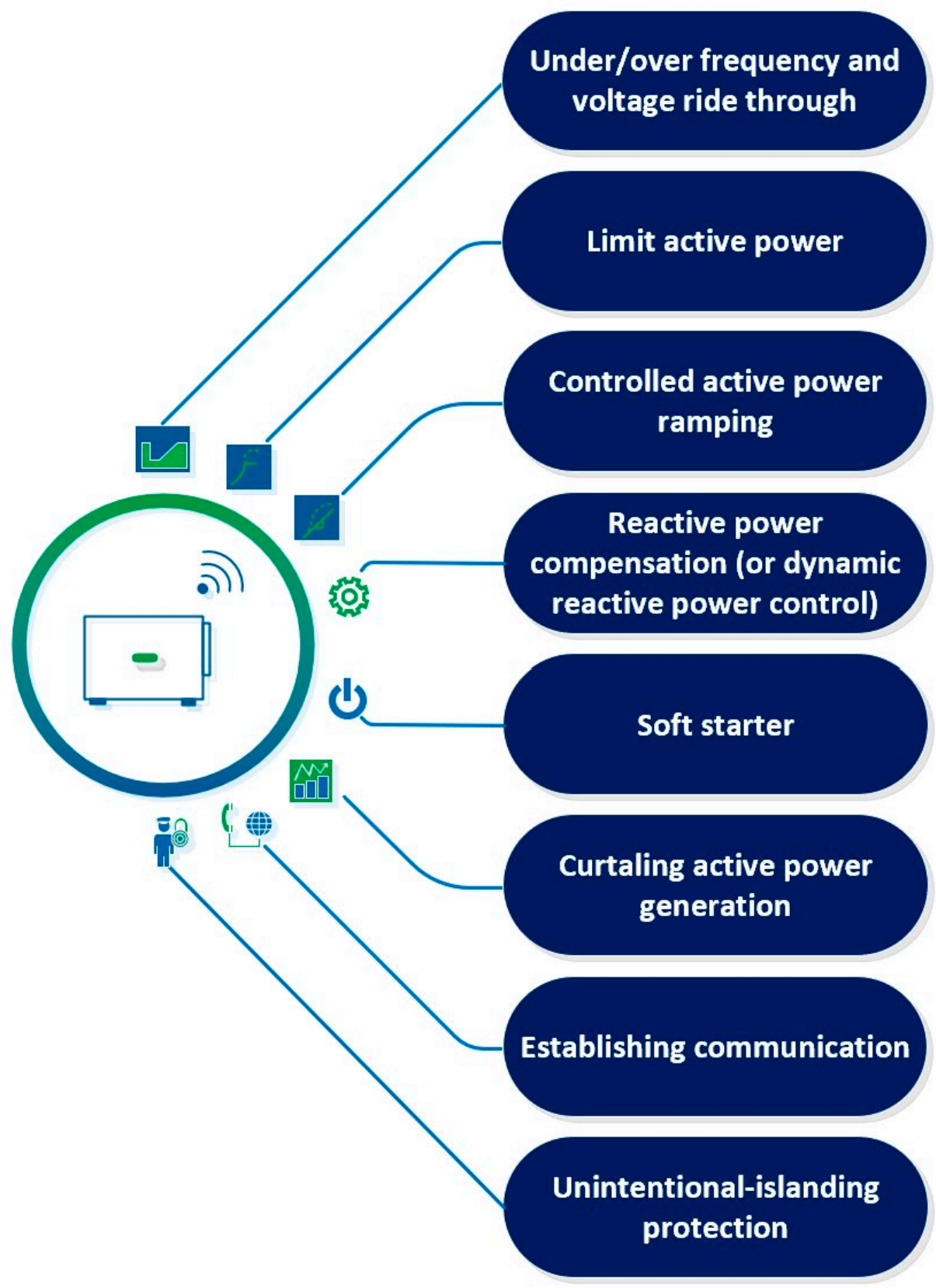

Figure 6. PV smart inverter benefits. 
Voltage control approaches with smart inverters fall into three categories: central, distributed, and decentralized (local) [163]. In [164], it has been specified that a local control strategy shows similarity to the primary response/control, which was the quickest and optimal approach to mitigate voltage fluctuations. To verify the effectiveness of the approach, a local control approach has been developed using the intelligent inverter control to alleviate the voltage fluctuations of the rooftop PVs. Moreover, the reactive power distribution required for a measured alteration in active power generation has been calculated. The results showed that the approach was efficient in decreasing the voltage fluctuations of local control as well as reducing concerns about voltage violations. The methods applied worldwide in the literature are summarized in Table 6 [21,135,163,165-167].

Table 6. Voltage Control Methods.

\begin{tabular}{|c|c|c|}
\hline Mitigation Method & Research Area & Results \\
\hline $\begin{array}{l}\text { The coordinating control of OLTC } \\
\text { and PV smart inverters }\end{array}$ & Taipower distribution systems in Taiwan & $\begin{array}{l}\text { The voltage quality of the system has been } \\
\text { increased, reducing the effect of high PV } \\
\text { integration in the distribution system }\end{array}$ \\
\hline Active network management & $\begin{array}{l}\text { 30-bus high PV penetrated LV } \\
\text { distribution network in Hobart, Australia }\end{array}$ & $\begin{array}{l}\text { It has been observed that it can match the } \\
\text { ideal central AC-OPF performance without } \\
\text { the need for communication, full network } \\
\text { observability, time delays and intensive } \\
\text { offline calculations }\end{array}$ \\
\hline $\begin{array}{c}\text { RPC and real power curtailment as a } \\
\text { comprehensive inverter control } \\
\text { strategy }\end{array}$ & Perth Solar City trial, Australia & Good for enhancing the power quality \\
\hline Droop-based APC techniques & $\begin{array}{l}\text { Typical 240-V /75-kVA Canadian } \\
\text { suburban distribution feeder with } 12 \\
\text { houses with roof-top PV systems }\end{array}$ & $\begin{array}{l}\text { It is concluded that sharing the power outage } \\
\text { among all customers results in a higher } \\
\text { amount of power outages }\end{array}$ \\
\hline Inverter Volt-Var control method & $\begin{array}{c}\text { Maui Advanced Solar Initiative Project in } \\
\text { Hawaii }\end{array}$ & $\begin{array}{l}\text { It has been observed that electrical power } \\
\text { utilities can control the distribution voltage } \\
\text { without installing additional devices in the } \\
\text { power network }\end{array}$ \\
\hline BESSs & $\begin{array}{l}33 \mathrm{kV} / 11 \mathrm{kV} \text { distribution substation in } \\
\text { the state of Queensland, Australia }\end{array}$ & $\begin{array}{l}\text { It is concluded that there is a significant } \\
\text { decrease in peak electricity demand with the } \\
\text { relatively high }(\sim 30 \%) \text { penetration of the PV } \\
\text { integrated BESS }\end{array}$ \\
\hline
\end{tabular}

\section{Summary of Discussion and State-of-the-Art Solutions}

Utilities and distribution companies expect their network systems to be reliable and stable. However, the integration of increasingly PV applications into grids is quite difficult due to their intermittent and unpredictable nature. To mitigate the negative effect of this integration, PV should be monitored more and optimized their usages. With technological development, researchers have been monitoring and optimizing the grid, but these processes are required so much data (known as big data) to be successful. Big data solutions require Optimization, Artificial Intelligence for more effective use of solar energy for the coming years in the short, medium, and long term. Conventional ways of mitigating the negative effect of PV integration would not be enough since technological development requires more sophisticated tools to deal with big data. Table 6 summarizes how the negative effect of PV installations are solved by using various techniques and devices including the use of optimization and artificial intelligence. That table clearly shows that problems with PV installation can be solved with Optimization and Artificial Intelligence methods and these methods are inevitable for the near future more since utilities/distribution system operators will be more dealing with data. 
Moreover, Table 7 summarizes the comparative analysis of DSM, OLTC, RPC, ESS, STATCOM, PV-GC, and smart inverter methods based on their advantage and disadvantages. It is clearly shown in Table 8 , each solution techniques have advantages and disadvantages that should be implemented based on needs.

Table 7. State-of-the-art solutions methods.

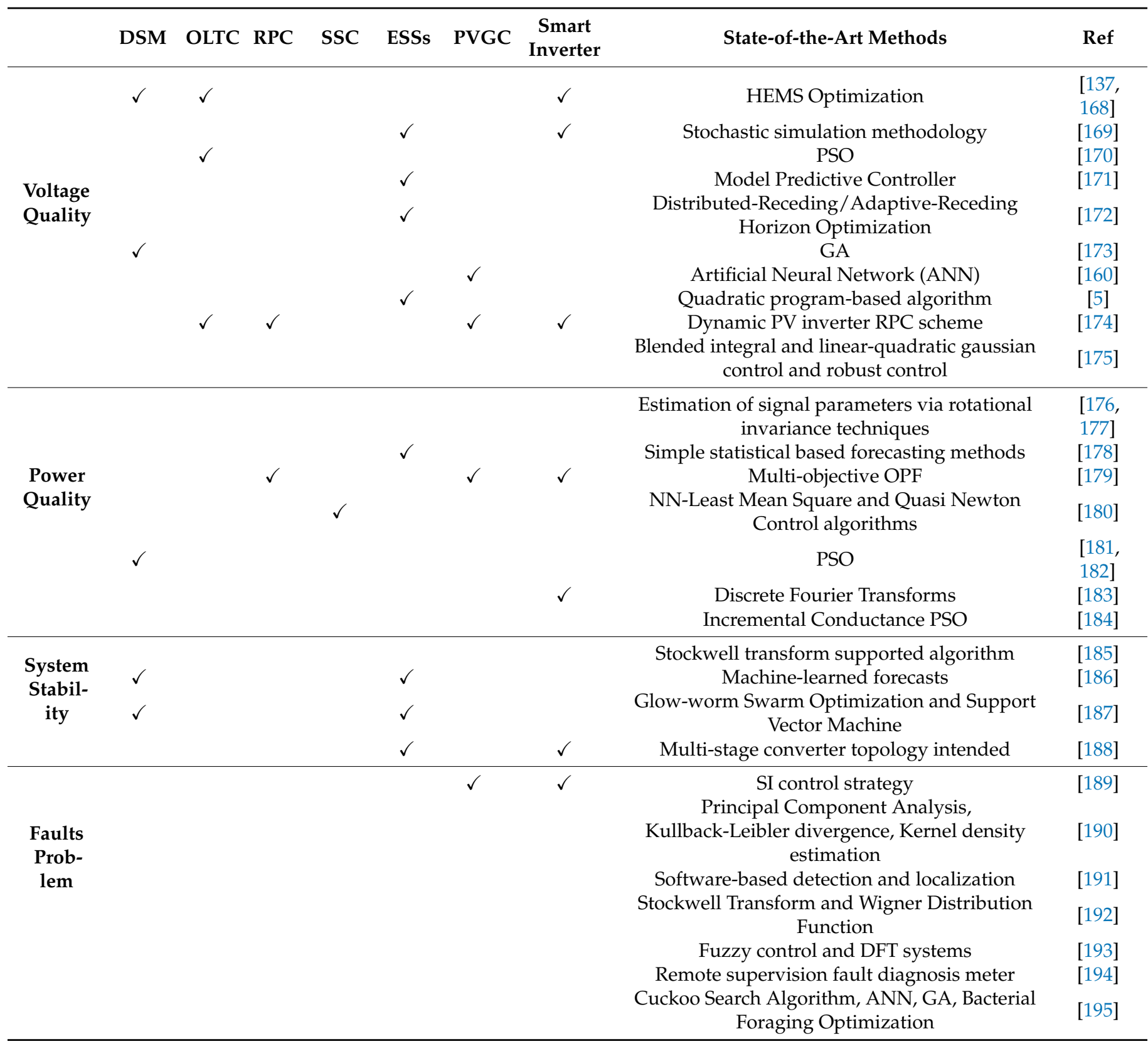


Table 8. Comparison of Advantages and Disadvantages among common methods.

\begin{tabular}{|c|c|c|c|}
\hline References & Methods & Advantage & Disadvantage \\
\hline [196] & DSM & $\begin{array}{l}\text { Provides load control } \\
\text { Increases the efficiency of system investment } \\
\text { Regulates the frequency } \\
\text { Provides security of supply } \\
\text { Lowers the production margin } \\
\text { Provides a more balanced use of } \\
\text { production/network consumption }\end{array}$ & $\begin{array}{l}\text { Grids should be improved for the use of } \\
\text { smart systems } \\
\text { No competition to traditional methods }\end{array}$ \\
\hline$[197,198]$ & OLTC & $\begin{array}{l}\text { Keeps the voltage within the nominal range } \\
\text { Increases system stability by providing voltage } \\
\text { control } \\
\text { Fault diagnosis }\end{array}$ & $\begin{array}{l}\text { Tap changers wear/tear due to arcing } \\
\text { Tap changers are damaged due to frequent } \\
\text { tap changing } \\
\text { High maintenance cost } \\
\text { slow switching }\end{array}$ \\
\hline [198] & RPC & $\begin{array}{l}\text { Improves tension quality } \\
\text { Increases PV-hosting capacity }\end{array}$ & $\begin{array}{l}\text { It is necessary to optimize the inverter droop } \\
\text { control parameters }\end{array}$ \\
\hline & & $\begin{array}{l}\text { Increases system flexibility } \\
\text { Energy arbitrage }\end{array}$ & \\
\hline$[199,200]$ & ESS & $\begin{array}{l}\text { Peak shaving } \\
\text { Supply capacity control } \\
\text { Frequency/Voltage regulation } \\
\text { Improves power quality } \\
\text { Reactive power support } \\
\text { Congestion management }\end{array}$ & $\begin{array}{l}\text { High initial cost } \\
\text { Low capacity } \\
\text { Short-term power support }\end{array}$ \\
\hline$[201,202]$ & STATCOM & $\begin{array}{l}\text { Quick response } \\
\text { Reducing power loss } \\
\text { Voltage stabilization } \\
\text { Power transmission capability } \\
\text { Harmonic filtering } \\
\text { Improving power quality }\end{array}$ & High initial cost \\
\hline [203] & PV-GC & $\begin{array}{l}\text { Voltage rise/fall control } \\
\text { Affordable cost }\end{array}$ & Loss of income \\
\hline [204] & $\begin{array}{l}\text { Smart } \\
\text { Inverter }\end{array}$ & $\begin{array}{l}\text { Helps in improving system stability } \\
\text { Provides power/voltage control } \\
\text { Management } \\
\text { Quick answer } \\
\text { Soft start } \\
\text { Ease of communication } \\
\text { Ramp rate control }\end{array}$ & High initial cost \\
\hline
\end{tabular}

\section{Conclusions}

Reaching a global carbon neutral economy will require a significant amount of renewable penetration of up to $85 \%$ in the future electricity mixture in the world. To reach this rate, many developed and developing countries have policies that support investment in renewable energy. Thanks to these policies, the increase in the amount of roof-mounted PV is exciting and has always been popular due to its low cost and easy applicability. However, when considering the future situation of PV globally, all risk scenarios should be addressed, and the most optimum solution methods should be developed. Some methods that alleviate the difficulties of increased PV penetration are addressed, in this article. Each solution has been produced based on a different effect and the purpose of this article is to use it as a source for future studies. In this detailed literature review, the impacts of rooftop PV systems on distribution systems, common solution techniques, and methods applied worldwide are summarized. The effects of a PV system on the distribution system are evaluated under four main headings: impacts on power quality, impacts on voltage quality, impacts on system stability, and impacts on protection systems. Solution methods that mitigate these effects are emphasized for the efficient, reliable, and safe operation of the PV system. Among the proposed methods, demand-side management, ESSs, PV-production 
outages, and results of smart inverter applications are discussed in a comparative manner. These methods can help solve problems such as voltage problems, instability in generation and consumption, RPF, instability, low power quality. However, since the problems that arise in a PV system can be very diverse, it is difficult to emphasize that a single method is the best method at the end of the research. Moreover, combining innovative methods brought by advancing technology with traditional methods in the coming years will increase the effectiveness of solution methods.

Funding: This research received no external funding.

Conflicts of Interest: The authors declare no conflict of interest.

\begin{tabular}{|c|c|}
\hline Abbreviation & \\
\hline Nomenclature & Meaning \\
\hline ANN & Artificial Neural Network \\
\hline $\mathrm{AI}$ & Artificial Intelligence \\
\hline APC & Active Power Curtailment \\
\hline BESS & Battery Energy Storage System \\
\hline DG & Distributed Generation \\
\hline DSM & Demand Side Management \\
\hline DSTATCOM & Distribution Static Synchronous Balancer \\
\hline DVR & Dynamic Voltage Regulator \\
\hline ESS & Energy Storage System \\
\hline FACTS & Flexible AC Transmission System \\
\hline GA & Genetic Algorithm \\
\hline GFDI & Ground Fault Detector Interrupter \\
\hline HEMS & Home Energy Management System \\
\hline LV & Low Voltage \\
\hline MPPT & Maximum Power Point Tracking \\
\hline $\mathrm{NN}$ & Neural Network \\
\hline OCPD & Overcurrent Protection Device \\
\hline OLTC & On Load Tap Changer \\
\hline OPF & Optimal Power Flow \\
\hline PCC & Point of Common Coupling \\
\hline P-PSO & Parallel-Particle Swarm Optimization \\
\hline PV & Photovoltaic \\
\hline PVGC & PV Generation Curtailment \\
\hline RPC & Reactive Power Control \\
\hline $\mathrm{RPF}$ & Reverse Power Flow \\
\hline SDBR & Series Dynamic Braking Resistor \\
\hline STATCOM & Static Synchronous Stabilizer \\
\hline SVC & Static Var Compensator \\
\hline TCSC & Thyristor Controlled Series Capacitor \\
\hline VR & Voltage Regulator \\
\hline
\end{tabular}

\section{References}

1. Schmela, M.; Beauvais, A.; Chevillard, N.; Paredes, M.G.; Heisz, M.; Rossi, R. Global Market Outlook For Solar Power 2018-2022; Africa-EU Renewable Energy Cooperation Programme (RECP), SolarPower Europerue: Brussels, Belgium; p. 92.

2. Wen, Q.; Liu, G.; Rao, Z.; Liao, S. Applications, evaluations and supportive strategies of distributed energy systems: A review. Energy Build. 2020, 225, 110314. [CrossRef]

3. Ariyaratna, P.M.; Muttaqi, K.M.; Sutanto, D. The simultaneous mitigation of slow and fast voltage fluctuations caused by rooftop solar PV by controlling the charging/discharging of an integrated battery energy storage system. J. Energy Storage 2019, 26, 100971. [CrossRef]

4. Cheng, D. Photovoltaic (PV) Impact Assessment for Very High Penetration Levels. IEEE J. Photovolt. 2016, 6, 295-300. [CrossRef]

5. Ratnam, E.L.; Weller, S.R.; Kellett, C.M. An optimization-based approach to scheduling residential battery storage with solar PV: Assessing customer benefit. Renew. Energy 2015, 75, 123-134. [CrossRef]

6. Nour, A.M.M.; Helal, A.A.; El-Saadawi, M.M.; Hatata, A.Y. A control scheme for voltage unbalance mitigation in distribution network with rooftop PV systems based on distributed batteries. Int. J. Electr. Power Energy Syst. 2021, 124, 106375. [CrossRef] 
7. Alam, M.J.E.; Muttaqi, K.M.; Sutanto, D. Effectiveness of traditional mitigation strategies for neutral current and voltage problems under high penetration of rooftop PV. In Proceedings of the 2013 IEEE Power \& Energy Society General Meeting, Vancouver, BC, Canada, 21-25 July 2013.

8. Weng, K.; Wan, Y.; Kumar, R. A review on performance of artificial intelligence and conventional method in mitigating PV grid-tied related power quality events. Renew. Sustain. Energy Rev. 2016, 56, 334-346.

9. Rohouma, W.; Balog, R.S.; Peerzada, A.A.; Begovic, M.M. D-STATCOM for harmonic mitigation in low voltage distribution network with high penetration of nonlinear loads. Renew. Energy 2020, 145, 1449-1464. [CrossRef]

10. Kharrazi, A.; Sreeram, V.; Mishra, Y. Assessment techniques of the impact of grid-tied rooftop photovoltaic generation on the power quality of low voltage distribution network-A review. Renew. Sustain. Energy Rev. 2020, 120, 109643. [CrossRef]

11. Hashemi, S.; Østergaard, J. Methods and strategies for overvoltage prevention in low voltage distribution systems with PV. IET Renew. Power Gener. 2017, 11, 205-214. [CrossRef]

12. Alboaouh, K.A.; Mohagheghi, S. Impact of Rooftop Photovoltaics on the Distribution System. J. Renew. Energy 2020, 2020, 1-23. [CrossRef]

13. Haque, M.M.; Wolfs, P. A review of high PV penetrations in LV distribution networks: Present status, impacts and mitigation measures. Renew. Sustain. Energy Rev. 2016, 62, 1195-1208. [CrossRef]

14. Shivashankar, S.; Mekhilef, S.; Mokhlis, H.; Karimi, M. Mitigating methods of power fluctuation of photovoltaic (PV) sources-A review. Renew. Sustain. Energy Rev. 2016, 59, 1170-1184. [CrossRef]

15. Maghami, M.R.; Hizam, H.; Gomes, C.; Radzi, M.A.; Rezadad, M.I.; Hajighorbani, S. Power loss due to soiling on solar panel: A review. Renew. Sustain. Energy Rev. 2016, 59, 1307-1316. [CrossRef]

16. Hsieh, W.; Lin, C.; Chen, C.; Hsu, C.; Ku, T.; Tsai, C.; Ho, C. Impact of PV generation to voltage variation and power losses of distribution systems. In Proceedings of the 2011 4th International Conference on Electric Utility Deregulation and Restructuring and Power Technologies (DRPT), Weihai, China, 6-9 July 2011; pp. 1474-1478.

17. Adefarati, T.; Bansal, R.C. Integration of renewable distributed generators into the distribution system: A review. IET Renew. Power Gener. 2016, 10, 873-884. [CrossRef]

18. Priye, A.; Komla, K. Voltage Rise Issue with High Penetration of Grid Connected PV; IFAC: Cape Town, South Africa, 25 August 2014; p. 47.

19. Katiraei, B.F. Studies for Utility-Scale Photovoltaic Distributed Generation. IEEE Power Energy Mag. 2011, 9, 62-71. [CrossRef]

20. Jayasekara, N.; Wolfs, P.; Masoum, M.A.S. An optimal management strategy for distributed storages in distribution networks with high penetrations of PV. Electr. Power Syst. Res. 2014, 116, 147-157. [CrossRef]

21. Su, X.; Masoum, M.A.S.; Wolfs, P.J. Optimal PV inverter reactive power control and real power curtailment to improve performance of unbalanced four-wire LV distribution networks. IEEE Trans. Sustain. Energy 2014, 5, 967-977. [CrossRef]

22. Ziadi, Z.; Taira, S.; Oshiro, M.; Funabashi, T. Optimal power scheduling for smart grids considering controllable loads and high penetration of photovoltaic generation. IEEE Trans. Smart Grid 2014, 5, 2350-2359. [CrossRef]

23. Camilo, F.M.; Castro, R.; Almeida, M.E. Assessment of overvoltage mitigation techniques in low-voltage distribution networks with high penetration of photovoltaic microgeneration. IET Renew. Power Gener. 2018, 12, 649-656. [CrossRef]

24. Elnozahy, M.S.; Salama, M.M.A. Technical impacts of grid-connected photovoltaic systems on electrical networks-A review. J. Renew. Sustain. Energy 2017, 2013, 032702. [CrossRef]

25. Alam, M.J.E.; Muttaqi, K.M.; Sutanto, D. Mitigation of Rooftop Solar PV Impacts and Evening Peak Support by Managing Available Capacity of Distributed Energy Storage Systems. IEEE Trans. Power Syst. 2013, 28, 3874-3884. [CrossRef]

26. Yao, E.; Samadi, P.; Wong, V.W.S.; Schober, R. Residential Demand Side Management Under High Penetration of Rooftop Photovoltaic Units. IEEE Trans. Smart Grid 2016, 7, 1597-1608. [CrossRef]

27. Mortazavi, H.; Mehrjerdi, H.; Saad, M.; Lefebvre, S.; Asber, D.; Lenoir, L. A Monitoring Technique for Reversed Power Flow Detection with High PV Penetration Level. IEEE Trans. Smart Grid 2015, 6, 2221-2232. [CrossRef]

28. Hatta, H.; Uemura, S.; Kobayashi, H. Cooperative control of distribution system with customer equipments to reduce reverse power flow from distributed generation. IEEE PES Gen. Meet. PES 2010, 2010, 10-15.

29. Chen, T.; Zheng, Y.; Chaudhuri, B.; Hui, S.Y.R. Distributed Electric Spring Based Smart Thermal Loads for Overvoltage Prevention in LV Distributed Network Using Dynamic Consensus Approach. IEEE Trans. Sustain. Energy 2020, 11, 2098-2108. [CrossRef]

30. Babacan, O.; Ratnam, E.L.; Disfani, V.R.; Kleissl, J. Distributed energy storage system scheduling considering tariff structure, energy arbitrage and solar PV penetration. Appl. Energy 2017, 205, 1384-1393. [CrossRef]

31. Al-Sabounchi, A.; Gow, J.; Al-Akaidi, M.; Al-Thani, H. Optimal sizing and location of a PV system on three-phase unbalanced radial distribution feeder avoiding reverse power flow. In Proceedings of the 2011 IEEE Electrical Power and Energy Conference, Winnipeg, MB, Canada, 3-5 October 2011; pp. 74-79.

32. Rasol, M.; Sedighi, A.; Savaghebi, M.; Guerrero, J.M. Optimal placement, sizing, and daily charge/discharge of battery energy storage in low voltage distribution network with high photovoltaic penetration. Appl. Energy 2018, 226, 957-966.

33. Unahalekhaka, P.; Sripakarach, P. Reduction of Reverse Power Flow Using the Appropriate Size and Installation Position of a BESS for a PV Power Plant. IEEE Access 2020, 8, 102897-102906. [CrossRef]

34. Hatta, H.; Asari, M.; Kobayashi, H. Study of energy management for decreasing reverse power flow from photovoltaic power systems. In Proceedings of the 2009 IEEE PES/IAS Conference on Sustainable Alternative Energy (SAE), Valencia, Spain, 28-30 September 2009. 
35. Kordkheili, R.A.; Pourmousavi, S.A.; Savaghebi, M.; Guerrero, J.M.; Nehrir, M.H. Assessing the potential of plug-in electric vehicles in active distribution networks. Energies 2016, 9, 34. [CrossRef]

36. Patil, A.; Girgaonkar, R.; Musunuri, S.K. Impacts of increasing photovoltaic penetration on distribution grid-Voltage rise case study. In Proceedings of the ICAGE 2014-International Conference on Advances in Green Energy, Melbourne, Australia, 25 February 2014; pp. 100-105.

37. Alshaikh, A.T.; Alquthami, T. Characterization of Voltage Rise Issue due to Distributed Solar PV Penetration. Int. J. Appl. Eng. Res. 2018, 13, 7522-7528.

38. Rafi, F.H.M.; Hossain, M.J.; Lu, J. Hierarchical controls selection based on PV penetrations for voltage rise mitigation in a LV distribution network. Int. J. Electr. Power Energy Syst. 2016, 81, 123-139. [CrossRef]

39. Liu, X.; Aichhorn, A.; Liu, L.; Li, H. Coordinated Control of Distributed Energy Storage System With Tap Changer Transformers for Voltage Rise Mitigation Under High Photovoltaic Penetration. IEEE Trans. Smart Grid 2012, 3, 897-906. [CrossRef]

40. Alam, M.J.E.; Muttaqi, K.M.; Sutanto, D. Distributed energy storage for mitigation of voltage-rise impact caused by rooftop solar. In Proceedings of the PV BT-2012 IEEE Power and Energy Society General Meeting, San Diego, CA, USA, $22-26$ July 2012.

41. Hasheminamin, M.; Agelidis, V.G.; Salehi, V.; Teodorescu, R.; Hredzak, B. Index-Based Assessment of Voltage Rise and Reverse Power Flow Phenomena in a Distribution Feeder under High PV Penetration. IEEE J. Photovolt. 2015, 5, 1158-1168. [CrossRef]

42. Huat, K.; Wong, J.; Seng, Y.; Taylor, P.; Morris, E.; Morris, S. Energy Procedia Mitigation of Voltage Unbalance in Low Voltage Distribution Network with High Level of Photovoltaic System. Energy Procedia 2011, 12, 495-501.

43. Pailwan, A.V.; Chatterjee, I.; Rajamani, K. Roof top photovoltaic grid integration: Utility approach. Int. Conf. Electr. Power Energy Syst. ICEPES 2017, 2016, 175-181.

44. Shahnia, F.; Ghosh, A.; Ledwich, G.; Zare, F. Electrical Power and Energy Systems Voltage unbalance improvement in low voltage residential feeders with rooftop PVs using custom power devices. Int. J. Electr. Power Energy Syst. 2014, 55, 362-377. [CrossRef]

45. Shahnia, F.; Ghosh, A.; Ledwich, G.; Zare, F. Voltage Unbalance reduction in low voltage distribution networks with rooftop PVs. In Proceedings of the 2010 20th Australasian Universities Power Engineering Conference, Christchurch, New Zealand, 5-8 December 2010.

46. Bletterie, B.; Kadam, S.; Pitz, R.; Abart, A. Optimisation of LV networks with high photovoltaic penetration-Balancing the grid with smart meters. In Proceedings of the 2013 IEEE Grenoble Conference, Grenoble, France, 16-20 June 2013.

47. Peng, W.; Haddad, S.; Baghzouz, Y. Improving power quality in distribution feeders with high PV penetration through inverter controls. In Proceedings of the CIRED 2012 Workshop: Integration of Renewables into the Distribution Grid, Lisbon, Portugal, 29-30 May 2012.

48. Panigrahi, R.; Mishra, S.K.; Srivastava, S.C. Grid integration of small-scale photovoltaic systems-a review. In Proceedings of the 2018 IEEE Industry Applications Society Annual Meeting (IAS), Portland, OR, USA, 23-27 September 2018.

49. Sikorski, T. Power quality in low-voltage distribution network with distributed generation. In Proceedings of the 2015 International School on Nonsinusoidal Currents and Compensation (ISNCC), Lagow, Polan, 15-18 June 2015.

50. Jayasekara, N.; Wolfs, P. Analysis of power quality impact of high penetration PV in residential feeders. In Proceedings of the 2010 20th Australasian Universities Power Engineering Conference, Christchurch, New Zealand, 5-8 December 2010.

51. Ebad, M.; Grady, W.M. An approach for assessing high-penetration PV impact on distribution feeders. Electr. Power Syst. Res. 2016, 133, 347-354. [CrossRef]

52. Ghiani, E.; Pilo, F. Smart inverter operation in distribution networks with high penetration of photovoltaic systems. J. Mod. Power Syst. Clean Energy 2015, 3, 504-511. [CrossRef]

53. Alam, M.J.; Muttaqi, K.M.; Sutanto, D. Mitigation of rapid voltage variations caused by passing clouds in distribution networks with solar PV using energy storage. In Proceedings of the 8th International Conference on Electrical and Computer Engineering, Dhaka, Bangladesh, 20-22 December 2014; pp. 305-308.

54. Babacan, O.; Torre, W.; Kleissl, J. Siting and sizing of distributed energy storage to mitigate voltage impact by solar PV in distribution systems. Sol. Energy 2017, 146, 199-208. [CrossRef]

55. Kraiczy, M.; Stetz, T.; Braun, M. Parallel operation of transformers with on load tap changer and photovoltaic systems with reactive power control. IEEE Trans. Smart Grid 2018, 9, 6419-6428. [CrossRef]

56. Bernal, A.E.; Lancheros-Cuesta, D.; Xie, J. Reactive power fluctuations smoothing in optimal control of grid-connected PV systems. In Proceedings of the 2017 IEEE 3rd Colombian Conference on Automatic Control (CCAC), Cartagena, Colombia, 18-20 October 2017.

57. Hao, H.; Yonghai, X.; Lin, Y. Control scheme of PV inverter under unbalanced grid voltage. In Proceedings of the 2014 IEEE PES General Meeting I Conference \& Exposition, National Harbor, MD, USA, 27-31 July 2014.

58. Hao, H.; Xu, Y. Control strategy of PV inverter under unbalanced grid voltage sag. In Proceedings of the 2014 IEEE Energy Conversion Congress and Exposition (ECCE), Pittsburgh, PA, USA, 14-18 September 2014; pp. 1029-1034.

59. Enslin, J.H.R. Integration of photovoltaic solar power-The quest towards dispatchability. IEEE Instrum. Meas. Mag. 2014, 17, 21-26. [CrossRef]

60. Obi, M.; Bass, R. Trends and challenges of grid-connected photovoltaic systems-A review. Renew. Sustain. Energy Rev. 2016, 58, 1082-1094. [CrossRef]

61. Hill, C.A.; Such, M.C.; Chen, D.; Gonzalez, J.; Grady, W.M. Battery Energy Storage for Enabling Integration of Distributed Solar Power Generation. IEEE Trans. Smart Grid 2012, 3, 850-857. [CrossRef] 
62. Darussalam, R.; Garniwa, I. The effect of photovoltaic penetration on frequency response of distribution system. In Proceedings of the 2018 International Conference on Sustainable Energy Engineering and Application (ICSEEA), Tangerang, Indonesia, 1-2 November 2018; Volume 2018, pp. 81-85.

63. Olowu, T.O.; Sundararajan, A.; Moghaddami, M.; Sarwat, A.I. Future Challenges and Mitigation Methods for High Photovoltaic Penetration: A Survey. Energies 2018, 11, 1782. [CrossRef]

64. Akshay, R.S.R.; Abraham, R.J. Load-frequency regulation with solar PV and battery energy storage system. Int. J. Power Energy Syst. 2019, 39, 10-16. [CrossRef]

65. Pinyol, R. Harmonics: Causes, Effects and Minimization; Salicru: Barcelona, Spain, 2015; pp. 1-32.

66. Lewis, S.J.; Engineer, G.; Energy, E. Analysis and Management of the Impacts of a High Penetration of Photovoltaic Systems in an Electricity Distribution Network. In Proceedings of the 2011 IEEE PES Innovative Smart Grid Technologies, Perth, WA, Australia, 13-16 November 2011.

67. Fekete, K.; Klaic, Z.; Majdandzic, L. Expansion of the residential photovoltaic systems and its harmonic impact on the distribution grid. Renew. Energy 2012, 43, 140-148. [CrossRef]

68. Hasan, R.; Mekhilef, S.; Seyedmahmoudian, M.; Horan, B. Grid-connected isolated PV microinverters: A review. Renew. Sustain. Energy Rev. 2017, 67, 1065-1080. [CrossRef]

69. Passey, R.; Spooner, T.; Macgill, I.; Watt, M.; Syngellakis, K. The potential impacts of grid-connected distributed generation and how to address them: A review of technical and non-technical factors. Energy Policy 2011, 39, 6280-6290. [CrossRef]

70. Sayadi, F.; Esmaeili, S.; Keynia, F. Two-layer volt/var/total harmonic distortion control in distribution network based on PVs output and load forecast errors. IET Gener. Transm. Distrib. 2017, 11, 2130-2137. [CrossRef]

71. Alquthami, T.; Sreerama, K.R.; Shaikh, A. Mitigation of voltage rise due to high solar PV penetration in Saudi distribution network. Electr. Eng. 2020, 102, 881-890. [CrossRef]

72. Reveles-Miranda, M.; Sánchez-Flórez, D.F.; Cruz-Chan, J.R.; Ordoñez-López, E.E.; Flota-Bañuelos, M.; Pacheco-Catalán, D. The Control Scheme of the Multifunction Inverter for Power Factor Improvement. Energies 2018, 11, 1662. [CrossRef]

73. Taghizadeh, M.; Sadeh, J.; Kamyab, E. Protection of grid connected photovoltaic system during voltage sag. In Proceedings of the 2011 International Conference on Advanced Power System Automation and Protection, Beijing, China, 16-20 October 2011; pp. 2030-2035.

74. Chen, X.; Zhang, Y.; Yang, J.; Chen, Y.; Wang, Q.; Zhou, N. Improved power control of photovoltaic generation system under unbalanced grid voltage conditions. In Proceedings of the Asia-Pacific Power Energy Eng. Conf. APPEEC, Kowloon, China, 8-11 December 2013; pp. 3-8.

75. Miret, J.; Castilla, M.; Camacho, A.; de Vicuña, L.G.; Matas, J. Control scheme for photovoltaic three-phase inverters to minimize peak currents during unbalanced grid-voltage sags. IEEE Trans. Power Electron. 2012, 27, 4262-4271. [CrossRef]

76. Yamashita, K.; Kitauchi, Y.; Kobayashi, H. Influence of voltage sags on the power system with high penetration of photovoltaic power generation. In Proceedings of the 2012 IEEE Power and Energy Society General Meeting, San Diego, CA, USA, 2226 July 2012.

77. Shen, W.; Zhu, Y. Impacts of small photovoltaic power station on voltage sag in low-voltage distribution network. In Proceedings of the 2011 International Conference on Electrical and Control Engineering, Yichang, China, 16-18 September 2011; pp. 1585-1588.

78. Hossain, M.K.; Ali, M.H. Low voltage ride through capability enhancement of grid connected PV system by SDBR. In Proceedings of the 2014 IEEE PES T\&D Conference and Exposition, Chicago, IL, USA, 14-17 April 2014.

79. Refaat, S.S.; Abu-Rub, H.; Sanfilippo, A.P.; Mohamed, A. Impact of grid-tied large-scale photovoltaic system on dynamic voltage stability of electric power grids. IET Renew. Power Gener. 2018, 12, 157-164. [CrossRef]

80. Yaghoobi, J.; Mithulananthan, N.; Saha, T.K. Dynamic voltage stability of distribution system with a high penetration of rooftop PV units. In Proceedings of the 2015 IEEE Power and Energy Society General Meeting, Denver, CO, USA, 26-30 July 2015; pp. 1-5.

81. Islam, M.; Mithulananthan, N.; Hossain, J.; Shah, R. Dynamic voltage stability of unbalanced distribution system with high penetration of single-phase PV units. J. Eng. 2019, 2019, 4074-4080. [CrossRef]

82. Kamaruzzaman, Z.A.; Mohamed, A.; Systems, E.; One, I. Dynamic voltage stability; power distribution system; grid-connected PV system. J. Electr. Syst. 2016, 2, 239-248.

83. Tbaileh, A.; Mishra, C.; Thomas, K. PV impacts on dynamic voltage stability. In Proceedings of the SoutheastCon 2017, Charlotte, NC, USA, 30 March-2 April 2017; pp. 3-7.

84. Kabir, S.; Krause, O.; Bansal, R.; Ravishanker, J. Dynamic voltage stability analysis of sub-transmission networks with large-scale photovoltaic systems. In Proceedings of the 2014 IEEE PES General Meeting I Conference \& Exposition, National Harbor, MD, USA, 27-31 July 2014.

85. Kamaruzzaman, Z.A.; Mohamed, A.; Shareef, H. Effect of grid-connected photovoltaic systems on static and dynamic voltage stability with analysis techniques-a review. Przeglad Elektrotechniczn 2015, 91, 134-138. [CrossRef]

86. Eftekharnejad, S.; Vittal, V.; Heydt, G.T.; Keel, B.; Loehr, J. Impact of increased penetration of photovoltaic generation on power systems. IEEE Trans. Power Syst. 2013, 28, 893-901. [CrossRef]

87. Kawabe, K.; Ota, Y.; Yokoyama, A.; Tanaka, K. Novel Dynamic Voltage Support Capability of Photovoltaic Systems for Improvement of Short-Term Voltage Stability in Power Systems. IEEE Trans. Power Syst. 2017, 32, 1796-1804. [CrossRef] 
88. Lakkireddy, J.; Rastgoufard, R.; Leevongwat, I.; Rastgoufard, P. Steady state voltage stability enhancement using shunt and series FACTS devices. In Proceedings of the 2015 Clemson University Power Systems Conference (PSC), Clemson, SC, USA, 10-13 March 2015.

89. Wang, D.; Yuan, X.; Zhao, M.; Qian, Y. Impact of large-scale photovoltaic generation integration structure on static voltage stability in China's Qinghai province network. J. Eng. 2017, 2017, 671-675. [CrossRef]

90. Du, W.; Zhou, M.; Lin, B.; Yang, G. Photovoltaic power penetration capacity assessment considering static voltage stability. In Proceedings of the 2013 IEEE PES Asia-Pacific Power and Energy Engineering Conference (APPEEC), Hong Kong, China, 8-11 December 2013.

91. Zaheb, H. A contemporary novel classification of voltage stability indices. Appl. Sci. 2020, 10, 1639. [CrossRef]

92. Li, S.; Wei, Z.; Ma, Y. Fuzzy load-shedding strategy considering photovoltaic output fluctuation characteristics and static voltage stability. Energies 2018, 11, 779. [CrossRef]

93. Roy, N.K.; Pota, H.R. Impact of high PV penetration into distribution networks under contingencies. In Proceedings of the 2013 IEEE International Conference on Smart Energy Grid Engineering (SEGE), Oshawa, ON, Canada, 28-30 August 2013.

94. Li, T.Y.; Han, Y.Q.; Hu, X.Q.; Pan, S.; Zhou, N.C. Characteristics of static voltage stability for distributed generation integrated into power system and its impacts analysis. In Proceedings of the 2013 IEEE PES Asia-Pacific Power and Energy Engineering Conference (APPEEC), Kowloon, China, 8-11 December 2013; Volume 42, pp. 8-13.

95. Rawat, M.S.; Vadhera, S. Impact of Photovoltaic Penetration on Static Voltage Stability of Distribution Networks: A Probabilistic Approach. Asian J. Water Environ. Pollut. 2018, 15, 51-62. [CrossRef]

96. Hu, L.; Liu, K.-Y.; Sheng, W.; Diao, Y.; Jia, D. Research on maximum allowable capacity of distributed generation in distributed network under global energy internet considering static voltage stability. J. Eng. 2017, 2017, 2276-2280. [CrossRef]

97. Ai, Q.; Wang, X.; He, X. The impact of large-scale distributed generation on power grid and microgrids. Renew. Energy 2014, 62, 417-423. [CrossRef]

98. Kazari, H.; Fard, A.A.T.; Dobakhshari, A.S.; Ranjbar, A.M. Voltage stability improvement through centralized reactive power management on the Smart Grid. In Proceedings of the 2012 IEEE PES Innovative Smart Grid Technologies (ISGT), Washington, DC, USA, 16-20 January 2012; pp. 1-7.

99. Aun, S.L.Z.; Marsadek, M.B.; Ramasamy, A.K. Small signal stability analysis of grid connected photovoltaic. Indones. J. Electr. Eng. Comput. Sci. 2017, 6, 553-562.

100. Gurung, S.; Naetiladdanon, S.; Sangswang, A. Impact of PV Penetration on Small Signal Stability Considering Uncertainties. Innov. Smart Grid Technol. 2016, 646-650.

101. Zeng, Z.; Yang, H.; Zhao, R. Study on small signal stability of microgrids: A review and a new approach. Renew. Sustain. Energy Rev. 2011, 15, 4818-4828. [CrossRef]

102. Wang, G.; Xin, H.; Wu, D.; Ju, P. Data-driven probabilistic small signal stability analysis for grid-connected PV systems. Int. J. Electr. Power Energy Syst. 2019, 113, 824-831. [CrossRef]

103. Xie, S.; Wang, X.; Qu, C.; Wang, X.; Guo, J. Impacts of different wind speed simulation methods on conditional reliability indices. Int. Trans. Electr. Energy Syst. 2013, 20,1-6.

104. Eftekharnejad, S.; Vittal, V.; Heydt, G.T.; Keel, B.; Loehr, J. Small signal stability assessment of power systems with increased penetration of photovoltaic generation: A case study. IEEE Trans. Sustain. Energy 2013, 4, 960-967. [CrossRef]

105. Liu, H.; Jin, L.; Le, D.; Chowdhury, A.A. Impact of high penetration of solar photovoltaic generation on power system small signal stability. In Proceedings of the 2010 International Conference on Power System Technology, Hangzhou, China, 24-28 October 2010; pp. $1-7$.

106. Bhattacharya, S.; Saha, T.; Hossain, M.J. Fault current contribution from photovoltaic systems in residential power networks. In Proceedings of the 2013 Australasian Universities Power Engineering Conference (AUPEC), Hobart, TAS, Australia, 29 September3 October 2013; pp. 1-6.

107. Baran, M.E.; Hooshyar, H.; Shen, Z.; Huang, A. Accommodating high PV penetration on distribution feeders. IEEE Trans. Smart Grid 2012, 3, 1039-1046. [CrossRef]

108. Li, B.; Wu, H.L.; Gao, X.Q. Investigation of protection schemes for high penetration rooftop photovoltaic system. In Proceedings of the 2011 International Conference on Advanced Power System Automation and Protection, Beijing, China, 16-20 October 2011; Volume 2, pp. 1299-1303.

109. Seguin, R.; Woyak, J.; Costyk, D.; Hambrick, J.; Mather, B. High-Penetration PV Integration Handbook for Distribution Engineers; NREL: Denver, CO, USA, 2016; pp. 1-109.

110. Pillai, D.S.; Rajasekar, N. A comprehensive review on protection challenges and fault diagnosis in PV systems. Renew. Sustain. Energy Rev. 2018, 91, 18-40. [CrossRef]

111. Alam, M.K.; Khan, F.; Johnson, J.; Flicker, J. A Comprehensive Review of Catastrophic Faults in PV Arrays: Types, Detection, and Mitigation Techniques. IEEE J. Photovolt. 2015, 5, 982-997. [CrossRef]

112. Falvo, M.C.; Capparella, S. Safety issues in PV systems: Design choices for a secure fault detection and for preventing fire risk. Case Stud. Fire Saf. 2015, 3, 1-16. [CrossRef]

113. Zhao, Y.; de Palma, J.F.; Mosesian, J.; Lyons, R.; Lehman, B. Line-line fault analysis and protection challenges in solar photovoltaic arrays. IEEE Trans. Ind. Electron. 2013, 60, 3784-3795. [CrossRef] 
114. Appiah, A.Y.; Zhang, X.; Ayawli, B.B.K.; Kyeremeh, F. Review and performance evaluation of photovoltaic array fault detection and diagnosis techniques. Int. J. Photoenergy 2019, 2019, 6953530. [CrossRef]

115. de Marco, Y.N.L.; Zheng, T.; Nikolovski, S. Overcurrent protection assessment with high PV penetration in a distribution network. Int. J. Renew. Energy Res. 2018, 8, 396-406.

116. Phayomhom, A.; Chaitusaney, S.; Rugthaicharoencheep, N.; Ainsuk, B. Impact of variable solar PV generation in MEA's power distribution system. In Proceedings of the 2015 IEEE Innovative Smart Grid Technologies-Asia (ISGT ASIA), Bangkok, Thailand, 3-6 November 2015; pp. 1-6.

117. Agamy, M.; Ndiaye, I. System Level Assessment of the Impact of High Penetration of PV Inverters with Grid Support Capability on Distribution Networks. In Proceedings of the 2019 IEEE 46th Photovoltaic Specialists Conference (PVSC), Chicago, IL, USA, 16-21 June 2019; pp. 2029-2036.

118. Alam, M.K.; Khan, F.H.; Johnson, J.; Flicker, J. PV faults: Overview, modeling, prevention and detection techniques. In Proceedings of the 2013 IEEE 14th Workshop on Control and Modeling for Power Electronics (COMPEL), Salt Lake City, UT, USA, 23-26 June 2013; pp. 1-7.

119. Zhao, Y.; Balboni, F.; Arnaud, T.; Mosesian, J.; Ball, R.; Lehman, B. Fault experiments in a commercial-scale PV laboratory and fault detection using local outlier factor. In Proceedings of the 2014 IEEE 40th Photovoltaic Specialist Conference (PVSC), Denver, CO, USA, 8-13 June 2014; pp. 3398-3403.

120. Yi, Z.; Etemadi, A.H. Fault detection for photovoltaic systems based on multi-resolution signal decomposition and fuzzy inference systems. IEEE Trans. Smart Grid 2017, 8, 1274-1283. [CrossRef]

121. Batman, A.; Bagriyanik, F.G.; Aygen, Z.E.; Gül, Ö.; Bagriyanik, M. A feasibility study of grid-connected photovoltaic systems in Istanbul, Turkey. Renew. Sustain. Energy Rev. 2012, 16, 5678-5686. [CrossRef]

122. Setlhaolo, D.; Xia, X. Combined residential demand side management strategies with coordination and economic analysis. Int. J. Electr. Power Energy Syst. 2016, 79, 150-160. [CrossRef]

123. Kallel, R.; Boukettaya, G.; Krichen, L. Demand side management of household appliances in stand-alone hybrid photovoltaic system. Renew. Energy 2015, 81, 123-135. [CrossRef]

124. Wu, Z.; Tazvinga, H.; Xia, X. Demand side management of photovoltaic-battery hybrid system. Appl. Energy 2015, 148, 294-304. [CrossRef]

125. Phiri, S.F.; Kusakana, K. Demand Side Management of a grid connected PV-WT-Battery hybrid system. In Proceedings of the 2016 International Conference on the Industrial and Commercial Use of Energy (ICUE), Cape Town, South Africa, 16-17 August 2016; pp. 45-51.

126. Barbato, A.; Capone, A. Optimization models and methods for demand-side management of residential users: A survey. Energies 2014, 7, 5787-5824. [CrossRef]

127. Iwafune, Y.; Ikegami, T.; Fonseca, J.G.D.S.; Oozeki, T.; Ogimoto, K. Cooperative home energy management using batteries for a photovoltaic system considering the diversity of households. Energy Convers. Manag. 2015, 96, 322-329. [CrossRef]

128. Mišák, S.; Stuchlý, J.; Platoš, J.; Krömer, P. A heuristic approach to active demand side management in off-grid systems operated in a smart-grid environment. Energy Build. 2015, 96, 272-284. [CrossRef]

129. Olatomiwa, L.; Uligwe, R.B.J. Demand Side Management Strategies for Solar-PV Penetration in Powering Rural Healthcare Centre in Africa; Loughborough University: Loughborough, UK, 2019.

130. Ibrik, I. Demand side management using grid-tied photovoltaic energy system. Int. J. Eng. Adv. Technol. 2019, 9, $4190-4194$.

131. Liu, J.; Chen, X.; Yang, H.; Li, Y. Energy storage and management system design optimization for a photovoltaic integrated low-energy building. Energy 2020, 190, 116424. [CrossRef]

132. Mak, D.; Choi, D.H. Optimization framework for coordinated operation of home energy management system and Volt-VAR optimization in unbalanced active distribution networks considering uncertainties. Appl. Energy 2020, 276, 115495. [CrossRef]

133. Elkazaz, M.; Sumner, M.; Naghiyev, E.; Pholboon, S.; Davies, R.; Thomas, D. A hierarchical two-stage energy management for a home microgrid using model predictive and real-time controllers. Appl. Energy 2020, 269, 115118. [CrossRef]

134. Martinez-Pabon, M.; Eveleigh, T.; Tanju, B. Optimizing residential energy management using an autonomous scheduler system. Expert Syst. Appl. 2018, 96, 373-387. [CrossRef]

135. Ku, T.T.; Lin, C.H.; Chen, C.S.; Hsu, C.T. Coordination of transformer on-load tap changer and pv smart inverters for voltage control of distribution feeders. IEEE Trans. Ind. Appl. 2019, 55, 256-264. [CrossRef]

136. Franco, J.F.; Procopiou, A.T.; Quirós-Tortós, J.; Ochoa, L.F. Advanced control of OLTC-enabled LV networks with PV systems and EVs. IET Gener. Transm. Distrib. 2019, 13, 2967-2975. [CrossRef]

137. Mak, D.; Choi, D.H. Smart home energy management in unbalanced active distribution networks considering reactive power dispatch and voltage control. IEEE Access 2019, 7, 149711-149723. [CrossRef]

138. Pukhrem, S.; Basu, M.; Conlon, M.F.; Sunderland, K. Enhanced Network Voltage Management Techniques Under the Proliferation of Rooftop Solar PV Installation in Low-Voltage Distribution Network. IEEE J. Emerg. Sel. Topics Power Electron. 2017, 5, 681-694. [CrossRef]

139. Chaudhary, P.; Rizwan, M. Voltage regulation mitigation techniques in distribution system with high PV penetration: A review. Renew. Sustain. Energy Rev. 2018, 82, 3279-3287. [CrossRef]

140. Yang, Y.; Wang, H.; Blaabjerg, F. Reactive power injection strategies for single-phase photovoltaic systems considering grid requirements. IEEE Trans. Ind. Appl. 2014, 50, 4065-4076. [CrossRef] 
141. Aziz, T.; Ketjoy, N. Enhancing PV Penetration in LV Networks Using Reactive Power Control and On Load Tap Changer With Existing Transformers. IEEE Access 2018, 6, 2683-2691. [CrossRef]

142. Bazrafshan, M.; Gatsis, N. Decentralized Stochastic Optimal Power Flow in Radial Networks with Distributed Generation. IEEE Trans. Smart Grid 2017, 8, 787-801. [CrossRef]

143. Pahwa, A. Goal-Based Holonic Multiagent System for Operation of Power Distribution Systems. IEEE Trans. Smart Grid 2015, 6, 2510-2518. [CrossRef]

144. Dall'Anese, E.; Dhople, S.V.; Johnson, B.B.; Giannakis, G.B. Decentralized optimal dispatch of photovoltaic inverters in residential distribution systems. IEEE Trans. Energy Convers 2014, 4, 957-967. [CrossRef]

145. Altin, N. Energy storage systems and power system stability. In Proceedings of the 2016 International Smart Grid Workshop and Certificate Program (ISGWCP), Istanbul, Turkey, 21-25 March 2016.

146. Ge, F.; Ye, B.; Wang, X.; Cai, Z.; Dai, L.; Hu, B. Technical and Economic Feasibility of Applying Battery Energy Storage for Enabling Voltage Stability of Grid-Connected Photovoltaic. Power Syst. 2018, 154, 196-202.

147. Yan, R.; Saha, T.K. Investigation of voltage stability for residential customers due to high photovoltaic penetrations. IEEE Trans. Power Syst. 2012, 27, 651-662. [CrossRef]

148. Ariyaratna, P.; Muttaqi, K.M.; Sutanto, D. A novel control strategy to mitigate slow and fast fluctuations of the voltage profile at common coupling Point of rooftop solar PV unit with an integrated hybrid energy storage system. J. Energy Storage 2018, 20, 409-417. [CrossRef]

149. Buchroithner, A. Decentralized low-cost flywheel energy storage for photovoltaic systems. In Proceedings of the 2016 International Conference on Sustainable Energy Engineering and Application (ICSEEA), Jakarta, Indonesia, 3-5 October 2016; pp. 41-49.

150. Wang, L.; Liang, D.; Crossland, A.; Wade, N.; Jones, D. Using a Smart Grid Laboratory to Investigate Battery Energy Storage to Mitigate the Effects of PV in Distribution Networks. In Proceedings of the 22nd International Conference and Exhibition on Electricity Distribution (CIRED 2013), Stockholm, Sweden, 10-13 June 2013; pp. 10-13.

151. Alam, M.J.E.; Muttaqi, K.M.; Sutanto, D. Alleviation of neutral-to-ground potential rise under unbalanced allocation of rooftop pv using distributed energy storage. IEEE Trans. Sustain. Energy 2015, 6, 889-898. [CrossRef]

152. Marra, F.; Yang, G.; Træholt, C.; Østergaard, J.; Larsen, E. A decentralized storage strategy for residential feeders with photovoltaics. IEEE Trans. Smart Grid 2014, 5, 974-981. [CrossRef]

153. Danish, S.M.S.; Ahmadi, M.; Danish, M.S.S.; Mandal, P.; Yona, A.; Senjyu, T. A coherent strategy for peak load shaving using energy storage systems. J. Energy Storage 2020, 32, 101823. [CrossRef]

154. Nour, A.M.M.; Hatata, A.Y.; Helal, A.A.; El-Saadawi, M.M. Review on voltage-violation mitigation techniques of distribution networks with distributed rooftop PV systems. IET Gener. Transm. Distrib. 2020, 14, 349-361. [CrossRef]

155. Oyegoke, S.; Habtay, Y.; Skarvelis-Kazakos, S. Contribution of inverter based photovoltaic generators to power quality at low voltage. In Proceedings of the 2015 50th International Universities Power Engineering Conference (UPEC), Stoke on Trent, UK, 1-4 September 2015; pp. 1-6.

156. Lata, L.; Elango, M.K. Voltage Sag Mitigation in Utility Distribution System Using STATCOM with Hysteresis Current Controller. Int. J. Adv. Res. Electr. Electron. Instrument. Eng. 2015, 4, 1261-1268.

157. Moghbel, M.; Masoum, M.A.S. D-STATCOM based on hysteresis current control to improve voltage profile of distribution systems with PV solar power. In Proceedings of the 2016 Australasian Universities Power Engineering Conference (AUPEC), Brisbane, QLD, Australia, 25-28 September 2016; pp. 1-5.

158. Wolfs, P.; Than, A.M. Improvements to LV distribution system PV penetration limits using a dSTATCOM with reduced DC bus capacitance. In Proceedings of the 2013 IEEE Power \& Energy Society General Meeting, Vancouver, BC, Canada, 21-25 July 2013; pp. 1-5.

159. Manzoni, R.C. Microgeneration Impact on LV Distribution Grids: A Review of Recent Research on Overvoltage Mitigation Techniques. Int. J. Renew. Energy Res. 2016, 6, 117-131.

160. Yap, W.K.; Havas, L.; Overend, E.; Karri, V. Neural network-based active power curtailment for overvoltage prevention in low voltage feeders. Expert Syst. Appl. 2014, 41, 1063-1070. [CrossRef]

161. Sevilla, F.R.S.; Parra, D.; Wyrsch, N.; Patel, M.K.; Kienzle, F.; Korba, P. Techno-economic analysis of battery storage and curtailment in a distribution grid with high PV penetration. J. Energy Storage 2018, 17, 73-83. [CrossRef]

162. Malekpour, A.H.; Pahwa, A.; Das, S. Inverter-based var control in low voltage distribution systems with rooftop solar PV. In Proceedings of the 2013 North American Power Symposium (NAPS), Manhattan, KS, USA, 22-24 September 2013; pp. 1-5.

163. Abadi, S.M.N.R.; Mahmoodi, M.; Scott, p.; Blackhall, L.; Thiebaux, S. Active Management of LV Residential Networks under High PV Penetration. In Proceedings of the 2019 IEEE Milan PowerTech, Milan, Italy, 23-27 June 2019; pp. 1-6.

164. Jha, R.R.; Dubey, A. Local Smart Inverter Control to Mitigate the Effects of Photovoltaic (PV) Generation Variability. In Proceedings of the 2019 North American Power Symposium (NAPS), Wichita, KS, USA, 13-15 October 2019; pp. 31-36.

165. Tonkoski, R.; Lopes, L.A.C.; El-Fouly, T.H.M. Coordinated active power curtailment of grid connected PV inverters for overvoltage prevention. IEEE Trans. Sustain. Energy 2011, 2, 139-147. [CrossRef]

166. Howlader, A.M.; Sadoyama, S.; Roose, L.R.; Sepasi, S. Distributed voltage regulation using Volt-Var controls of a smart PV inverter in a smart grid: An experimental study. Renew. Energy 2018, 127, 145-157. [CrossRef] 
167. Mardira, L.; Saha, T.K.; Eghbal, M. Investigating impacts of battery energy storage systems on electricity demand profile. In Proceedings of the 2014 Australasian Universities Power Engineering Conference (AUPEC), Perth, WA, Australia, 28 September-1 October 2014; pp. 1-5.

168. Dao, V.T.; Ishii, H.; Takenobu, Y.; Yoshizawa, S.; Hayashi, Y. Home Energy Management Systems under Effects of Solar-Battery Smart Inverter Functions. IEEJ Trans. Electr. Electron. Eng. 2020, 15, 692-703. [CrossRef]

169. Sousa, J.F.B.; Borges, C.L.T.; Mitra, J. PV hosting capacity of LV distribution networks using smart inverters and storage systems: A practical margin. IET Renew. Power Gener. 2020, 14, 1332-1339. [CrossRef]

170. Rahman, M.M.; Arefi, A.; Shafiullah, G.M.; Hettiwatte, S. A new approach to voltage management in unbalanced low voltage networks using demand response and OLTC considering consumer preference. Int. J. Electr. Power Energy Syst. 2018, 99, 11-27. [CrossRef]

171. Fortenbacher, P.; Ulbig, A.; Andersson, G. Optimal Placement and Sizing of Distributed Battery Storage in Low Voltage Grids Using Receding Horizon Control Strategies. IEEE Trans. Power Syst. 2018, 33, 2383-2394. [CrossRef]

172. Ratnam, E.L.; Weller, S.R. Receding horizon optimization-based approaches to managing supply voltages and power flows in a distribution grid with battery storage co-located with solar PV. Appl. Energy 2018, 210, 1017-1026. [CrossRef]

173. Asgher, U. Smart energy optimization using heuristic algorithm in smart grid with integration of solar energy sources. Energies 2018, 11, 3494. [CrossRef]

174. Malekpour, A.R.; Pahwa, A. A Dynamic Operational Scheme for Residential PV Smart Inverters. IEEE Trans. Smart Grid 2017, 8, 2258-2267. [CrossRef]

175. Datta, D.; Fahim, S.R.; Sarker, S.K.; Muyeen, S.M.; Islam Sheikh, M.R.; Das, S.K. A Robust Control Method for Damping and Tracking of Secondary Network Voltage of a PV Based Hybrid AC/DC Microgrid. Front. Energy Res. 2020, 580840. [CrossRef]

176. Santos, E.; Khosravy, M.; Lima, M.A.A.; Cerqueira, A.S.; Duque, C.A.; Yona, A. High accuracy power quality evaluation under a colored noisy condition by filter bank ESPRIT. Electronics 2019, 8, 1259. [CrossRef]

177. Santos, E.; Khosravy, M.; Lima, M.A.A.; Cerqueira, A.S.; Duque, C.A. ESPRIT associated with filter bank for power-line harmonics, sub-harmonics and inter-harmonics parameters estimation. Int. J. Electr. Power Energy Syst. 2020, 118, 105731. [CrossRef]

178. Litjens, G.B.M.A.; Worrell, E.; van Sark, W.G.J.H.M. Assessment of forecasting methods on performance of photovoltaic-battery systems. Appl. Energy 2018, 221, 358-373. [CrossRef]

179. Su, X.; Masoum, M.A.S.; Wolfs, P. Comprehensive optimal photovoltaic inverter control strategy in unbalanced three-phase four-wire low voltage distribution networks. IET Gener. Transm. Distrib. 2014, 8, 1848-1859. [CrossRef]

180. Pragathi, B.; Nayak, D.K.; Poonia, R.C. Mitigation of power quality issues for grid connected photo voltaic system using soft computing techniques. J. Interdisci. Math. 2020, 23, 631-637. [CrossRef]

181. Pinto, R.; Bessa, R.J.; Matos, M.A. Multi-period flexibility forecast for low voltage prosumers. Energy 2017, 141, $2251-2263$. [CrossRef]

182. Bayat, M.; Sheshyekani, K.; Rezazadeh, A. A Unified Framework for Participation of Responsive End-User Devices in Voltage and Frequency Control of the Smart Grid. IEEE Trans. Power Syst. 2015, 30, 1369-1379. [CrossRef]

183. Bighash, E.Z.; Sadeghzadeh, S.M.; Ebrahimzadeh, E.; Blaabjerg, F. Adaptive-harmonic compensation in residential distribution grid by roof-top PV Systems. IEEE J. Emerg. Sel. Top. Power Electron. 2018, 6, 2098-2108. [CrossRef]

184. Chawda, G.S.; Mahela, O.P.; Gupta, N.; Khosravy, M.; Senjyu, T. Incremental conductance based particle swarm optimization algorithm for global maximum power tracking of solar-PV under nonuniform operating conditions. Appl. Sci. 2020, 10, 1-16.

185. Mahela, O.P. Recognition of Power Quality Issues Associated With Grid Integrated Solar Photovoltaic Plant in Experimental Framework. IEEE Syst. J. 2020, 1-9. [CrossRef]

186. Simmons, C.R.; Arment, J.R.; Powell, K.M.; Hedengren, J.D. Proactive energy optimization in residential buildings withweather and market forecasts. Processes 2019, 7, 929. [CrossRef]

187. Puttamadappa, C.; Parameshachari, B.D. Demand side management of small scale loads in a smart grid using glow-worm swarm optimization technique. Microprocess. Microsyst. 2019, 71, 102886.

188. Devi, V.K.; Premkumar, K.; Beevi, A.B. Energy management using battery intervention power supply integrated with single phase solar roof top installations. Energy 2018, 163, 229-244. [CrossRef]

189. Wang, W.; de Leon, F. Quantitative Evaluation of der Smart Inverters for the Mitigation of FIDVR in Distribution Systems. IEEE Trans. Power Deliv. 2020, 35, 420-429. [CrossRef]

190. Bakdi, A.; Bounoua, W.; Mekhilef, S.; Halabi, L.M. Nonparametric Kullback-divergence-PCA for intelligent mismatch detection and power quality monitoring in grid-connected rooftop PV. Energy 2019, 189, 116366. [CrossRef]

191. Kersten, A. Fault detection and localization for limp home functionality of three-level NPC inverters with connected neutral point for electric vehicles. IEEE Trans. TransElectrif. 2019, 5, 416-432. [CrossRef]

192. Kulshrestha, A.; Mahela, O.P.; Gupta, M.K.; Gupta, N.; Patel, N.; Senjyu, T.; Danish, M.S.S.; Khosravy, M. A Hybrid Fault Recognition Algorithm Using Stockwell Transform and Wigner Distribution Function for Power System Network with Solar Energy Penetration. Energies 2020, 13, 3519. [CrossRef]

193. Saifuddin, M.R.B.M.; Logenthiran, T.; Naayagi, R.T.; Woo, W.L. Apprehending Fault Crises for an Autogenous Nanogrid System: Sustainable Buildings. IEEE Syst. J. 2019, 13, 3254-3265. [CrossRef]

194. Chao, K.H.; Chen, C.T. A remote supervision fault diagnosis meter for photovoltaic power generation systems. Meas. J. Int. Meas. Confed. 2017, 104, 93-104. [CrossRef] 
195. Kalaam, R.N.; Muyeen, S.M.; Al-Durra, A.; Hasanien, H.M.; Al-Wahedi, K. Optimisation of controller parameters for gridtied photovoltaic system at faulty network using artificial neural network-based cuckoo search algorithm. IET Renew. Power Gener. 2017, 11, 1517-1526. [CrossRef]

196. Strbac, G. Demand side management: Benefits and challenges. Energy Policy 2008, 36, 4419-4426. [CrossRef]

197. Ram, G.; Prasanth, V.; Bauer, P.; Barthlein, E.M. Comparative analysis of on-load tap changing (OLTC) transformer topologies. In Proceedings of the 2014 16th International Power Electronics and Motion Control Conference and Exposition, Antalya, Turkey, 21-24 September 2014; Volume 2014, pp. 918-923.

198. Jin, L.; Cai, Y. A Review of Fault Diagnosis Research on On-Load Tap-Changers. E3S Web Conf. 2020, 155, 1-7. [CrossRef]

199. Mazman, M.; Yilmaz, C.H. Enerji Depolama Çözümleri ve Genel Eğilimler. Elektrik Mühendisliği 2019, 466, 32-40.

200. Kocer, M.C.; Cengiz, C.; Gezer, M.; Gunes, D.; Cinar, M.A.; Alboyaci, B.; Onen, A. Assessment of Battery Storage Technologies for a Turkish Power Network. Sustainability 2019, 11, 3669. [CrossRef]

201. Barrios-Martínez, E.; Ángeles-Camacho, C. Technical comparison of FACTS controllers in parallel connection. J. Appl. Res. Technol. 2017, 15, 36-44. [CrossRef]

202. Yoldaş, Y.; Önen, A.; Muyeen, S.M.; Vasilakos, A.V.; Alan, İ. Enhancing smart grid with microgrids: Challenges and opportunities. Renew. Sustain. Energy Rev. 2017, 72, 205-214. [CrossRef]

203. Tonkoski, R.; Lopes, L.A.C. Impact of active power curtailment on overvoltage prevention and energy production of PV inverters connected to low voltage residential feeders. Renew. Energy 2011, 36, 3566-3574. [CrossRef]

204. Lulbadda, K.T.; Hemapala, K.T.M.U. The additional functions of smart inverters. AIMS Energy 2019, 7, 971-988. [CrossRef] 